$\begin{array}{cc}\text { Türk Coğrafya Dergisi } \\ \text { Basılı ISSN 1302-5856 } & \text { Turkish Geographical Review } \\ & \text { www.tcd.org.tr }\end{array}$

\title{
İkinci konut turizminin tarımsal kaynaklar üzerindeki baskısı: Pelitköy örneği ${ }^{1}$
}

\section{Pressure on agriculture resources of second homes tourism: Case of Pelitköy Village}

\author{
Serdar Ceylan *a (D) Mehmet Somuncu ${ }^{\text {b }}$ \\ ${ }^{a}$ Kastamonu Üniversitesi, Fen-Edebiyat Fakültesi, Coğrafya Bölümü, Kastamonu. \\ ${ }^{b}$ Ankara Üniversitesi, Dil ve Tarih-Coğrafya Fakültesi, Coğrafya Bölümü, Ankara.
}

ORCID: S.C. 0000-0002-9599-5586; M.S. 0000-0001-8890-0537

\section{BILGI / INFO}

Geliş/Received: 10.01.2020

Kabul/Accepted: 12.08 .2020

\section{Anahtar Kelimeler:}

ikinci konut turizmi

kıyı alanları

arazi kullanımı

Pelitköy

Burhaniye

Keywords:

Second home tourism

coast lands

land use

Pelitköy

Burhaniye

*Sorumlu yazar/Corresponding author:

(S. Ceylan)

serdarceylan@kastamonu.edu.tr

DOI: $10.17211 /$ tcd. 673115

\begin{abstract}
ÖZ / ABSTRACT
Kentsel nüfusun tatil gereksinimlerine karşıık olarak kıyı alanlarında artan ikinci konutlar, kıyı arazileri üzerinde yoğun bir baskı oluşturmaktadır. Araştırmanın amacı, ikinci konut turizminin kıyı alanlarında zeytin arazilerini ne yönde etkilediğinin incelenmesidir. Nitel araştırma yönteminde, yorumlayıcı yaklaşımda yapılan çalışmada yerel halk ile görüşmeler yapılmıştır. Görüşmeler ses kaydına alınarak çözümlenmiştir. Sahada gözlemlerde bulunulmuştur. Ampirik bulgular ve kurumsal veriler, çalışmada betimsel olarak analiz edilmiştir. Araştırma bulgularına göre, Pelitköy kıyılarında yer alan zeytinlik alanlar ikinci konut siteleri tarafindan işgal edilmiş durumdadır. İkinci konutlar, araştırma alanının \%13'lük kısmını oluşturmaktadır. Kıyı alanı, daha önce zeytin üretim alanı iken, günümüzde ikinci konut alanına dönüşmüştür. Zeytin üretimi için kullanılan tarım arazisinin geleceği, ikinci konut turizmi baskısı altındadır. Doğru politikalar ve yasal düzenlemeler yapılmazsa, tarım arazileri ortadan kalkacaktır.
\end{abstract}

Second homes which are increased for holiday requirement of urban society in coast areas have pressed on agriculture lands in coast regions. The aim of study is to understand effects of second homes tourism on olive lands. In the study made by qualitative method and phenomenology approach, made interviews with local people. The voices of people that interview made recorded and they analyzed as descriptive later. Moreover, in research area was made observation. The study's all findings were analyzed as descriptive. According to results of the study, olive lands were occupied by second homes that formed 13 percent of all the land in the research area. The coastal area was transformed into a second house settlement, while it was previously an olive production area. Future of agriculture land that has used for olive production, is under pressure of second homes tourism. If right policies and legal regulations aren't established, agriculture lands will disappear.

\section{Atff/Citation}

Ceylan, S. ve Somuncu, M. (2020). íkinci konut turizminin tarımsal kaynaklar üzerindeki baskısı: Pelitköy örneği. Türk Coğrafya Dergisi (75), 41-56.

DOI: $10.17211 /$ tcd.673115

\section{Extended Abstract Introduction}

The demand for the coasts is increasing day by day and revenue arising from tourism investments causes destruction of rural areas (Sesli et al., 2003: 757). Tourist facilities in coastal areas and recreational activities have caused deterioration of rural areas (Akyarlı et al., 2002; 66). Turkey coasts was exposed to construction density, after opening the sea tourism in

\footnotetext{
${ }^{1} \mathrm{Bu}$ çalışma birinci yazarın doktora tezinden faydalanılarak hazırlanmıştır.

${ }^{1}$ This study has been prepared by using the PhD thesis of the first author.
} 
1980s (Güzer, 2010; Birol-Özerk, 2012: 30). While these areas in developing countries such as Turkey, "development" purposes is used, however in these fields of developed countries "protection" is come to the fore (Tümertekin and Özgüç, 1998: 378-379; Bakırcı, 2007a: 24). Because of industrialization, urbanization and tourism, coastal areas of Turkey is losing their identity. Separation of forest and agriculture lands into secondary residences causes the texture of the coastal areas to deteriorate (Idil, 1989). Agriculture and tourism stand out as two land uses on the coasts in Turkey. The increase in the number of visitors on the coasts increases the pressure on these areas, as well (Kızılgün, 2001). Sector with the most pressure to Turkey's coast are tourism and the second housing sector (Duru, 2003; Alpaslan and Ortaçeşme, 2009: 169-170). Activities in touristic areas where are intense of agricultural activities, cause the disappearance of fertile agricultural lands (Samırkaş and Bahar, 2013: 12-13). As a result, because of the development of second homes in coasts, agricultural lands has transformed to urban lands in turkey coasts (Mizan, 1994: 83).

\section{Research Area}

Research area is located in Burhaniye which is district of Balıkesir province in Aegean region. The basic economic activity is olive agriculture in the study area. The coastals of the research area is covered with second homes today. Village settlement area (Pelitköy) that is living 2478 people (2018) is located 4 km inland from the coast. Local people living in the research area are still engaged in olive cultivation in coastal areas. Moreover, there are 5 olive oil factories (or facility) in the study area.

\section{Method}

The aim of study is to understand effects of second homes tourism on olive lands. The pressing of second homes tourism and changing in land use are the subject of this research In the study made by qualitative method and phenomenology approach, made interviews with local people. Interviews voices recorded and they analyzed as descriptive later. Moreover, in case study area was made observation. The study's all findings were analyzed as descriptive. Research question: What is the relationship between secondary housing tourism and the use of agricultural lands?

\section{Result and Discussion}

According to results of the study, olive lands were occupied by second homes that formed 13 percent of all the land in the research area. The coastal area was transformed into a second house settlement, while it was previously an olive production area. Future of agriculture land that has used for olive production, is under pressure of second homes tourism. If right policies and legal regulations aren't established, agriculture lands will disappear.

In rural areas which is done tourism and provides a different motivation to visitors, land using is changing. Moreover, changing of land use is caused to diferentiation of the area as economic and social. The coasts of the research area have undergone a transformation because of the second homes tourism since the 1980s. The traditional (agricultural) use of the land were changed by the city population for tourism purposes. This situation is cause to the reduction of agricultural land and change of coastal texture. This change is also has causes the ownership of coastal areas to change hands. In other words, in addition to the change in the purpose of use of the soil, the user them land has also changed. Rural landscape is changed from olive fileds to leisure consuption in the research area.

The main livelihood of local people living in the study area is the olive agriculture. Therefore, olive trees and olive fields should be protected on the coastal. To ensure the sustainability of agricultural activities, protection and use balance must be observed in the coasts. Sustainable use of groundwater should be ensured and integrated natural resource management should be applied on the coasts. In the coast planning, the deterioration of the agricultural landscape shoul be prevented, the density of construction (second housing) on the coasts should be controlled. By ensuring sustainability in agriculture, the destruction of agricultural resources that will be left to future generations should be prevented. As a result, tourism activities that take place without planning cause the unconscious use of agricultural lands and the agricultural lands are rapidly consumed with an unsustainable approach. In policies to be made for coastal areas, it should be prevented that tourism and industrial activities affect agricultural areas.

\section{Giriş}

Turizm faaliyetleri ile kırsal alanlar geleneksel kullanımından (tarım, hayvancılık) sıyrılarak çok fonksiyonlu kırsal alanlara doğru evrilmektedir. Turizme konu olan ve ziyaretçilere farklı bir motivasyon sağlayan bu tür kırsal alanlarda arazinin kullanımı da farklılaşmaktadır. Kırsal alanlarda turizm faaliyetlerinin gelişmesiyle birlikte yerel halkın sosyo-ekonomik ve sosyo-kültürel durumu da değişebilmektedir. Yaşanan bu değişim ve dönüşüm bütüncül olarak ifade edilecek olursa, turizmin çevresel anlamda arazi kullanımını etkilemesinin yanı sıra, ekonomik ve sosyal olarak da alanın farklılaşmasını beraberinde getirmektedir.

Uryy'e (2015: 336) göre kırsal alanlar, pazaryeri aracılığıyla hızlı bir şekilde metalaştırılma sorunu ile karşılaşmaktadır. Woods'a (2005) göre, kırsal peyzaj ve yaşam sitili, turizm ve rekreasyon yoluyla kullanılmak için pazarlanmaktadır. Bu gelişimin arkasındaki dinamik güç, kırsal aktiviteler içerisinde gelişen piyasa ilişkileridir. Tarım, ormancılık ve diğerleri için kırsal arazinin geleneksel kullanımının görece değeri azalmakta, tüketilecek bir yer (place) olarak bu alanların değeri artmaktadır (Cloke, 1993; Murdoch vd., 2003, Woods, 2005). Meta ve meta formları olarak kırsal çekicilikler giderek metalaştırılmaktadır. Günümüzde bu alanların metalaştırılarak yeniden inşa edilmesi, kırsal mekânı anlamada giderek önem kazanmaktadır (Crouch, 2006: 355). Yapılan bazı araştırmalarda, kırsal mekânları ve diğer ürünleri satmak için kırsal imajın kullanımı bir metalaştrrma olarak görülmez iken, bazı yeni araştırmacı gruplar tarafindan bu durum, kırsalın sömürülmesi üzerine temelli bir metalaşttrma olarak görülmektedir (Marsden, 1998a; Woods, 2005; Crouch, 2006). Tüm bunlar birlikte düşünüldüğünde, kırsal alanların hem arazi kullanımı ve sosyal kompozisyon bakımından hem de ilk üretimin üstünlüğünün kaybı bakımından durum daha heterojen olmaktadır. Kırsal peyzaj, farklı arazi 
kullanımı ve kalkınma baskısı tarafından daha karmaşık bir hal almaktadır (Halfacree, 1998; Hall, vd., 2003). Turizm ve rekreasyonel faaliyetler, birçok bölgede kırsal dönüşümler üzerinde nüfuz edici bir gücü bulunmaktadır. Rekreasyon ve boş zaman aktivitelerinden dolayı, "kırsal rekreasyonel bölge (rural recreational countryside)" (Halseth, 2004: 34-35) ve "zevk çevresi (pleasure periphery)" (Müller, 2005) gibi yeni kavramlar, primer üretimden ziyade boş zaman tüketim yerleri olarak, kırsal alanları tanımlamak için türetilmektedir. Batı dünyasının kırsal alanlarında göç ve turizm hareketi, artan bir şekilde önemli olmakta ve bu durum tarım içinde kısmen dönüşümlerin bir sonucu olmaktadır. Bunun anlamı, artk kırsal alanlarda tarımın olmaması demek değildir; ama tarım kırsal alanlardaki baskın gücünü artık kaybetmektedir (Marsden, 1998b; Holmes, 2006). Bat dünyasının çoğu kırsal alanında, özellikle hem genç hem de kadın nüfus arasında önemli bir oranda dışarı göç yaşanmaktadır. Bazı kırsal alanlarda bu, nüfusun azalmasına ve yaşlı nüfusun artmasına neden olmaktadır. Bu durum, tarım endüstrisindeki değişimle birlikte sosyal ve ekonomik problemlere de yol açmaktadır (Swarbrooke, 1999; Müller, 2005; Overvag, 2009: 20-22). Dışardan gelen ikinci konut sahipleri karşısında, yerel halkın alanda kendisini yabancı hissetmesi, sahil kenarlarının yerel halkın kullanımına kapatılması, yazın görülen aşırı insan hareketliliği ve trafik sorunu; arsa ve konut piyasasının yükselmesi, sebze ve meyve gibi ürünlerde fiyatlarının artması, yerel halkın tarımsal arazisini satarak topraksız kalması ve üretici pozisyonunu kaybetmesi nedeniyle giderek yoksullaşması gibi durumlar ikinci konut alanlarında görülen temel sorunlardır. Bu durum, kırsal alanların doğal çekiciliklerinin turizm için pazarlanmasının bir sonucudur.

Perkins (2006), kırsal dönüşüme yol açan süreçleri bütüncül olarak "metalaştırma" olarak değerlendirmektedir. Metalaştırma; kırsal alanların yeni kaynakları olarak anlayacağımız "kırsal üretim" ve "kırsal tüketimin" birlikteliği ve "yeni kırsal coğrafyanın" kuruluşunun temelini oluşturmaktadır. Perkins'e göre kırsal dönüşüm ve metalaştırma; herhangi bir zamanda (kaynak, çevresel yönetim ve planlama araçları gibi) yerel, bölgesel ve küresel sistemlerden güçlü bir şekilde etkilenmektedir. Ancak Perkins'e göre bu metalaştırma değerleri, kırsal alanların tamamı üzerinde egemenlik kurmamaktadır (Overvag, 2009: 23). Kırsal toplumların ve arazi kullanımının metalaşması ve değişmesinin ardındaki ana dinamik güç, dış ilişkiler ve kentsel nüfusun artan önemidir. Ortaya çıkan çevreciler, tüketiciler, imarcılar ve kentin diğer ilgi grupları, kırsal alanların nasıl kullanılabileceği ve yönetileceği üzerine hak iddia etmektedirler (Marsden, 1999; Cheshire, 2006). Yeni kırsal arazi kullanımı, kırsal nüfusun eylemlerinden etkilenerek değişmekte; ancak bu arazilerin esas dönüşümü, çeşitli diğer dış nüfusun kırsal alanları ziyaret etmesi ve bu alanlara yerleşmesiyle olmaktadır (Halfacree, 2006; Perkins, 2006). Bu dış etkiler, sadece imarcılar, çevreci gruplar ve gıda tüccarları tarafindan değil, aynı zamanda turistler ve rekreasyonel konut sahiplerinin varlığından da kaynaklanmaktadır (Floysand ve Jakobsen, 2007). Rekreasyonel (ikinci) konutlar, aynı zamanda turizmin bir tipi olarak görülebilir. Turizm, rekreasyonel faaliyetler ve tarımsal endüstri, kırsal bölgelerin kullanımında dönüşümlere neden olmakta ve kırsal alanların çevre, arazi kullanımı, ekonomi ve siyasi konumundaki değişimlere katkıda bulunan ana faktörler olarak ortaya çıkmaktadır (Ilbery, 1998; Woods, 2005). Butler'a (1998) göre, turizm ve rekreasyonel faaliyetlerle ilişkili olarak kırsal alanlarda meydana gelen bu dönüşüm, son on yılda meydana gelenler içerisinde en önemlileri arasında yer almaktadır. Woods'a (2005) göre turizm, üretim üzerine temelli bir ekonomiden tüketim üzerine temelli bir ekonomiye doğru kırsal alanların geçişinde en görünür bir faktör olmaktadır. Kırsal alanların turizm ve rekreasyon amaçlı kullanımı için talebin ileride daha da artacağı düşünülmektedir (Butler, 1998; Hall vd., 2003; Overvag, 2009: 21-24). İkinci konutların turizmin ve rekreasyon amaçlı olarak kırsal alanlarda yoğunlaşması, kıyılarda yeni yerleşimlerin açılmasına ve bu alanların giderek kentleşmeye doğru bir dönüşüm geçirmesine neden olmaktadır. Başka bir deyişle, tarımsal üretim yeri olan ve kırsal nüfus tarafindan yoğun olarak kullanılan bu alanlar, turizmin alana gelmesiyle birlikte üretimden çok bir tatil (tüketim) mekânı olmakta ve kentli nüfus tarafindan kullanılmaktadır.

\section{Literatür}

\subsection{Turizm ve İkinci Konutların Kıуı Alanları Üzerindeki Etkisi}

Zengin bir potansiyele sahip kıyılarda talep her geçen gün artmakta, turizm ve endüstri yatırımlarından doğan rant, geri dönüşümü olmayan tahribatları beraberinde getirmektedir (Sesli vd., 2003: 757). Kıyı alanlarındaki turistik tesisler ve bazı eğlence anlayışları da bu alanların bozulmasına yol açabilmektedir (Akyarlı vd., 2002; 66). Belki dünyadaki bütün turistik kullanımların ticari hale gelmesinin ortaya çıkardığı bu sorunun tam olarak çözümünün bulunması mümkün değildir (Tekeli, 1971: 276). Örneğin kıyılarda boş zamanın artması dolayısıyla turizm faaliyetlerindeki artış kıyılardaki kumsalları ekonomik bakımdan çok çekici hale getirmekte; ancak kumsalların çevresine yığılan turizm yatırımlarının hızla özelliklerini yitirmesine neden olmaktadır. Kıyıların kıyı şeridi boyunca farklılaşmış olması dolayısıyla kıyıların özel niteliklere sahip olarak oluşmuş kesimleri üzerinde tahrip edici baskıları yüksek olmaktadır (Tekeli, 2014: 255). Türkiye kıyılarında turizm potansiyelinin keşfedilmesinden sonra kıyı yerleşkesinin çoğu hazırlıklı olmadıkları bir yapılaşma yoğunluğu ile karşı karşıya kalmış, özgün ve tarihi dokuları kıyı kenarlarından başlamak üzere dönüşüme uğramıştır. Bu dönüşümün getirdiği niteliksiz ve çevreye duyarsız yapı stoğu, kıyı yapılaşması konusunu Türkiye mimarlık alanı için özel bir sorun alanı olarak öne çıkarmıştır (Güzer, 2010; Birol-Özerk, 2012: 30). Türkiye gibi gelişmekte olan ülkelerde bu alanlar "kalkınma" amaçlı kullanılırken, gelişmiş ülkelerde bu alanların "korunması" ön plana çıkmaktadır (Tümertekin ve Özgüç, 1998: 378-379; Bakırcı, 2007a: 24).

Yapılı çevrenin üretiminde Türkiye'de devlet müdahalesinin son yıllardaki artı̧̧ı çok hızlı gerçekleşmektedir. Kamu arazilerinin turizm, toplu konut, alışveriş merkezleri gibi projelere tahsis edilmesi ve satılması, kıyılardaki tarım alanlarının ve doğal ve tarihi sit alanlarının turizme açılması, belediyelerin ve kamu-özel sektör ortakların bu projeleri hayata geçirebilmesi için kurumsal yapılar olarak düzenlenmesi, planlama yetkilerinin devlet kurumları arasında dağıtılarak mekân müdahalenin önünün açılması devletin müdahale biçimlerinden bazılarıdır (Mukul ve Sarı, 2015: 901-902). Türkiye kıyılarının iç ve dış turizm talebine bağlı olarak yoğun bir nüfus baskısı altına girmesi (Akova, 2019) ikinci konut ve tatil siteleri yapımı, koruma alanlarında günübirlik turizm adına yapılan uygulamalar, denize yapılan dolgular, ulaşım sorunu adına gerçekleştirilen 
otoyollar ve daha birçok uygulamalar kıyılarının yok olmasına neden olmaktadır (Çelik, 2015: 37). Konaklama tesisleri, ikinci konutlar, devre mülkler, devre tatil siteleri gibi tesislerle ülke kıyılarında hızla yoğun bir yapılaşma görülmektedir. Konaklama tesisleri ve ikinci konutlar, kıyıları kaplamaktadır. Ayrıca yüksek kıyılarda ve eğimli yamaçlarda denize ancak asansörle bağlant kurulabilen konaklama tesisleri ve devre mülkler yapılmaktadır. Türkiye'nin özellikle Akdeniz ve Ege kıyılarında turizm; plansız gelişmeye ve yasal düzenlemelerle kırsal yerleşim birimlerinde kentleşmeye, orman ve tarım alanlarında yapılaşmaya, kıyılardaki jeomorfolojik şekillerinin tahribine ve hatta bu doğal yapıların geri kazanılması olanaksız zararına neden olmaktadır (Doğaner, 2001: 30-34). Türkiye kıyılarındaki alanlar sanayileşme, kentleşme ve turizm etkinlikleriyle kimliklerini yitirmektedir. Artan nüfusun gereksinimlerini karşılamak için altyapının geliştirilmesi, sanayi ve turizm tesislerine ya da enerji santrallerine kıyıda yer verilmesi, kıyı kuşağı boyunca çoğu kez denizin doldurulmasıyla yol geçirilmesi, ormanlık ve tarım alanlarının ikinci konutlar ya da işyerleri için ayrılması gibi uygulamalar, kıyı alanlarının dokusunun bozulmasına yol açmaktadır (İdil, 1989). Günümüzde Türkiye'de kentsel yığılmanın ve kıyılardaki ikinci konutların kontrol altına alınamaması, kıyı kanunun yetersizliği, mevcut arazi kulanım planlarının revize edilmemesi ülke kıyılarında birçok soruna neden olmaktadır (Akyarlı vd., 2002: 68). Örneğin Manavgat-Side kıyılarında turizmin hızla gelişmesine paralel olarak artan turizm yatırımları, özellikle 1990 yılından itibaren önemli ölçüde nüfus artı̧̧ına neden olmuştur. Nüfustaki bu artş̧ beraberinde fiziksel alan ve altyapı ihtiyacını getirmiş olup, kıyıda bulunan tarım ve orman alanları, kentsel alanlara, ikinci konut yerleşmelerine ve turizm merkezlerine dönüşmüştür (Alpaslan ve Ortaçeşme, 2009: 170).

\subsection{Turizmin ve İkinci Konutların Tarım Üzerindeki Etkisi}

Tarım ve turizm, kıyılardaki iki temel arazi kullanımı olarak göze çarpmaktadır. Türkiye'de turizm kullanımı özellikle son 25 yılda önemli gelişme kaydetmiş, gelen turist sayısındaki artışa paralel olarak, kıyısal kaynaklar üzerinde önemli baskılar oluşturmuştur (Kızılgün, 2001). Türkiye kıyılarına en fazla baskı yapan sektörler, turizm ve bununla birlikte gelişen ikinci konut sektörüdür. Turizm hareketleri Türkiye'de 1970'li yıllardan sonra hızlanmış, 1980'lerde turizm kaynaklı gelirleri artırmak üzere alınan önlemler turist sayısında artş̧a neden olmuştur. 1982 yılında çıkartılan Turizm Teşvik Kanunu, Türkiye'de kitle turizminin gelişmesinde bir dönüm noktası olmuştur. Bu yasayla, bir yandan bu alandaki girişimleri desteklemek üzere özel önlemler getirilirken, diğer yandan bozulmamış kıyı alanları, verimli tarım toprakları, tarihsel ve doğal değerler turizmin hizmetine sunulmuştur (Duru, 2003; Alpaslan ve Ortaçeşme, 2009: 169-170). Türkiye'de ikinci konutların niceliksel ve niteliksel sıçraması 1980'li yıllarda belirginleşmiştir. 1985 sonrası ise, sayısal artışın ve dönüşümün dorukta olduğu yıllar olmuştur. 1980'li yılların sonu ve 1990'lı yıllarda plan sınırları genişletilerek yapılaşmaya eğimli alanlar nazım ve uygulama planları kapsamı içine alınmış, bir taraftan da hızlı yapay yerel yönetim oluşumları körüklenmiştir (Koç ve Seymen, 1995). Bu durum yer yer tarım arazisi açsından verimli toprakların ikinci konut alanlarına açılmasına neden olmuştur (Bakırcı, 2007b: 38).
Tarımsal faaliyetlerin yoğun olduğu turistik bölgelerde turizmin hızla ilerlemesi ve düzensiz mekân kullanımı sonucunda tarıma ayrılan verimli alanlar giderek azalmaktadır. Tarımsal arazideki bu daralma, aynı zamanda tarım sektöründeki üretim arzının da daralmasına neden olmaktadır. Turizmin gelişmesi, tarımsal alanlardaki bazı geleneksel işlerin (balıkçılık, ormancılık gibi) terk edilmesine neden olmakta ve bu da yerel işgücünün azalmasına ve dış tedarikçilere bağımlı kalınmasına neden olabilmektedir. Tarımsal faaliyetlerin yoğun olduğu bölgelerde, verimli tarım arazilerinin imara açılması ve ormanlık alanlarda turizm tesislerine ve ikinci konutlara izin verilmesi hem ormanlık alanların hem de fauna ve flora türlerinin yok olmasına neden olmaktadır (Samırkaş ve Bahar, 2013: 12-13). $\mathrm{Bu}$ nedenle kırsal alanların yeniden yapılanmasında "karlılık" tek belirleyici ölçüt olmaktan çıkmakta, biyolojik çeşitliliği korumak, doğal kaynakların sürdürülebilirliğini sağlamak, gıda güvenliğini sağlamak gibi kaygılar önem kazanmaktadır. Bu bağlamda "tarımsal üretimi iç ve dış talebe uyumlu hale getirirken, sürdürülebilirliği sağlamak, doğal ve biyolojik kaynakları korumak ve geliştirmek", Türkiye'nin 1980 sonrasında uyguladığı tarım politikaları olmuştur (Tekeli, 2016: 65-67).

Turizmin kırsal alanlarda gelişmesiyle beraber, ikinci konut yapımı ve satın alımında da artş̧lar söz konusu olmakta, bu ise turizm bölgelerindeki yerel ekonomiler üzerinde olumsuz etkiler meydana getirmektedir. Büyük kapasiteli turizm yatırımları ile yarışamayan ve herhangi bir turizm geliri olmayan yerel halkın, faaliyette bulunduğu tarım alanının zamanla azalması, o bölgede yaşayan insanların ekonomik açıdan marjinal bir duruma düşmesine neden olmaktadır (Bahar ve Kozak, 2005: 169). Son yıllarda denize kıyısı olan bölgelerde değerli tarım alanları da kolay kazanç sağlamasından dolayı ikinci konut ve turistik amaçlı kullanımlara dönüştürülmüştür. Bunda 1985 yılında imar planı hazırlama görevinin yerel yönetimlere verilmesinin etkisi büyük olmuştur (Kurt, 2015: 644). Tarım ve hayvancılık faaliyetleriyle geçinen kırsal yerleşmelerde çiftçinin tarımsal faaliyetler (zirai ilaç, zirai alet, traktör, tohum, gübre, mazot, yem vb.) için sermayeye (finansa) ihtiyaç duyması, kendisini borçlanmaya itmektedir. Tekeli'nin de ifade etiği üzere, çiftçi yaşamını ve üretimini sürdürebilmek için borçlanmaktadır; ancak borçlarını ödemek için zorlandıklarında toprağı satma yerine hayvanını ya da traktörünü satma eğiliminde olmaktadır (Tekeli, 2016: 83). Ancak traktör ve hayvanı olmayan aileler, toprağını satarak nakite dönüştürmekte ve toprak satışından elde ettiği parayı intiyacı doğrultusunda kullanabilmektedir.

İkinci konutların tarımsal toprakları kullanması, kırsal alanlarda ikinci konut turizminin gelişiminde en önemli çıktılardan biri olarak görülmektedir (Keshavarznia vd., 2013: 182). İkinci konutların gelişimi, kıyı kasabalarının çevrelerindeki kırsal alanları hızla kentsel arazilere dönüştürmektedirler. Bu alanların büyük bir çoğunluğunun tarım arazileri ve doğal bitki örtülerinin bulunduğu alanlar oluşturmaktadır. Zengin tarım topraklarının yok olması olayın ekonomik boyutunu, bitki örtüsünün, yaban hayatının yok edilmesi ve çevre kirliliğinin yükselmesi olayın çevresel boyutunu, yerel halk üzerindeki olumsuz etkileri ise sosyal (toplumsal) boyutunu oluşturmaktadır (Mizan, 1994: 83). Türkiye'de merkezi ve yerel yönetimlerinin kıyı yerleşmelerine tümüyle birer kalkınma ve ekonomik gelişme aracı olarak yaklaşması, kıyılardaki yapılaşmanın hızla artmasına neden olmakta, bunun sonucunda ise kıyı alanların- 
daki kaynaklar hızla tahrip edilmektedir. İkinci konutların kıyı alanlarında artışı, tarım ve orman alanlarının, çeşitli bitki ve hayvan türlerinin yok olmasına, kaynakların aşırı kullanılmasına ve çevre kirliliğine neden olmaktadır (Birol-Özerk, 2012: 31-32). Örneğin Silivri (Sertkaya-Doğan, 2011), Erdemli (Kara, 1984; Şahin, 1998), Silifke, Kuşadası (Dal ve Baysan, 2007; Emekli, 2008; Güney ve Somuncu, 2018), Alanya'da (Salihoğlu ve Gezici-Korten, 2016) yer alan tarım alanları turizm amaçlı yapılaşmadan zarar görmüştür. Bunun en olumsuz etkisi, özel ürün alanlarının (muz, narenciye, zeytin) yapılaşmaya açılmasıdır. Turizm; kırsal mekânların görünümünü, ekili alanlar arasından geçen karayolları, yüksek konaklama tesisleri ve yöresel mimariye uymayan ikinci konutlarla bozmaktadır (Doğaner, 2001: 31). Kıyılardaki verimli tarım topraklarında ve ormanlık alanlarda plansız bir biçimde yer alan ve yılın sadece belli bir döneminde kullanılan ikinci konutlar ise, bulundukları bölgede yoğunluğu artırarak büyük altyapı sorunlarına neden olmaktadır (Seymen ve Koç, 1996; Alpaslan ve Ortaçeşme, 2009: 170).

İç turizmin yapay çevre üzerindeki en dikkat çekici etkileri ikinci konut alanlarında görülmektedir. İkinci konut gelişiminin çevresel öğeler ve peyzaj üzerinde önemli etkilerini daha detaylı bir şekilde sıralamak mümkündür (Özkan, 1993; Türkoğlu vd., 1989, Arkon, 1989; Mizan, 1994, 31-32). Orman ya da zeytinlik alanlar tahrip edilmekte ve bu alanların yerine ikinci konutlar inşa edilmektedir. Diğer tarım alanı sahipleri de ikinci konutlara sahip olmak isteyen kimselerin cazip teklifleri karşısında baskı altında kalmaktadırlar. İkinci konutların yapımı sırasında toprağın yüzey bitkilerinden arındırılması ve sonrasında gelen yapılaşma sırasında gerekli önlemlerin alınmaması zorunlu yol ve benzeri altyapı çalışmaları, erozyonu hızlandırmaktadır. Kıyı sulak alanları kurutularak oluşturulan ikinci konut yapılaşmaları kıyı gerisindeki arazilerde taban suyunu düşürerek tarım alanlarının olumsuz etkilenmesine de neden olmaktadır.

İkinci konutlar nedeniyle tarım alanlarında görülen değişim- ler, bağcılık amaçlı olarak yapılan ve daha sonra sayfiye amaçIı kullanılan bağ evlerinde de görülmektedir. Somuncu'nun (1996) Kayseri'de bağcılık üzerine yapmış olduğu araştırmaya baktığımızda, bağ evlerinin sayfiye amaçlı olarak yüzyıllarca kullanıldığı; ancak günümüzde Kayseri'de artan ulaşım imkânları ve toplumsal refah düzeyinin yükselmesiyle günümüzdeki kullanımının geleneksel bağcılıktan rekreasyon amaçıı kullanıma doğru evrildiği görülmektedir. Sönmez'in (2013) bağcılık üzerine Gaziantep'te yapmış olduğu araştırmada da benzer sonuçlara ulaşth̆̆ı görülmektedir. Gaziantep'te bağ evlerinin 1960'larda tarımsal amaçlı olarak inşa edildiği ve dönemlik olarak kullanıldığı; ancak 1990'lardan itibaren dinlenmek (rekreasyon) amaçlı olarak bu evlerden hafta sonlarında ve yaz dönemlerinde yararlanıldığı belirlenmiştir. Ayrıca yörede "bağ evi" olarak bilinen bazı konutların günümüzde yerini, modern yapı malzemeli ve çok katlı (dubleks, tripleks) ikinci konutlara bıraktı̆̆ tespit edilmiştir. Gaziantep'in Alleben Deresi Vadisi ve yakın çevresi, 1970'li yıllara kadar şehrin meyve ve sebze ihtiyacı karşılayan önemli bir tarım alanı iken, günümüzde bu tarım alanı şehrin hızlı kentleşmesi ve yatay olarak büyümesi sonucu yok olduğu ve buradaki bağ evlerinin yerini ikinci konutlara bıraktı̆̆ belirlenmiştir. Alpaslan ve Ortaçeşme (2009) araştırmasında, Side Manavgat kıyı kesiminde 1981-2003 yılı arasında arazi kullanımında önemli ölçüde dönüşümler olduğunu tespit etmiştir. Bu araştirma sonuçlarına göre; orman alanları 207 ha, tarım alanları ise 625 ha, plaj alanları 113 ha, kumul alanları 68 ha, çalılık ve otsu örtülü doğal alanlar 131 ha daralmıştır. Ancak buna karşılık otel ve tatil köyleri alanı 496 ha, ikinci konut yerleşim alanları 123 ha artş̧ göstermiştir. Kumul alanların \%25'i turizm tesisi ve ikinci konut alanlarına dönüşerek kıyılardaki yapılaşma yoğunluğu artmıştır. Alandaki yoğun yerleşim ve ikinci konut talebi, yeni yerleşim alanlarının açılmasına da neden olmuş, kırsal alanlar imar planları yapmak suretiyle konut alanlarına dönüşmüştür. Kanat ve Demir (2008) Sapanca köylerindeki araşttrmasında, köylülerin kentten gelen yazlıkçılara topraklarını satarak toprağını elinden çı-

Tablo 1. Görüşme Yapılan Katılımcılara İlişkin Bilgiler

Table 1. Information about participants who was made interviewees

\begin{tabular}{|c|c|c|c|c|c|c|c|c|c|c|c|}
\hline Kod & Cinsiyet & Yaş & Eğitim & İşi & Paydaş & Kod & Cinsiyet & Yaş & Eğitim & İşi & Paydaş \\
\hline K1 & Kadın & 65 & Lise & Emekli & Yazlıkçı & K17 & Erkek & 65 & İlkokul & Emekli & Yerel halk \\
\hline K2 & Erkek & $65+$ & Lisans & Emekli & Yazlıkçı & K18 & Erkek & $65+$ & illkokul & Emekli & Yerel halk \\
\hline K3 & Kadın & $65+$ & Lise & Emekli & Yazlıkçı & K19 & Erkek & 55 & İlkokul & Çiftçi & Yerel halk \\
\hline K4 & Erkek & $65+$ & Lisans & Emekli & Yazlıkçı & $\mathrm{K} 20$ & Erkek & $40+$ & Lise & Çiftçi & Yerel halk \\
\hline K5 & Erkek & $65+$ & illkokul & Emekli & Yazlıkçı & K21 & Erkek & 52 & Ortaokul & Çiftçi & Yerel halk \\
\hline K6 & Kadın & $60+$ & Ortaokul & Emekli & Yazlıkçı & K22 & Erkek & $65+$ & İlkokul & Emekli & Yerel halk \\
\hline K7 & Erkek & $65+$ & Lisans & Emekli & Yazlıkçı & K23 & Erkek & $65+$ & İlkokul & Emekli & Yerel halk \\
\hline K8 & Kadın & $65+$ & Lise & Emekli & Yazlıkçı & K24 & Erkek & 40 & Ortaokul & Çiftçi -Muhtar & Yerel halk \\
\hline K9 & Erkek & $65+$ & Lisans & Emekli & Yazlıkçı & K25 & Erkek & $45+$ & Lise & Kafe İşletmeci & İşletmeci \\
\hline K10 & Erkek & $65+$ & Lisans & Emekli & Yazlıkçı & K26 & Erkek & $45+$ & İlkokul & Seyyar Satıcı & İşletmeci \\
\hline K11 & Erkek & 46 & ilkokul & Çiftçi & Yerel halk & K27 & Erkek & $50+$ & Lisans & Memur/Yönetici & Belediye \\
\hline K12 & Erkek & 43 & Ortaokul & Çiftçi & Yerel halk & K28 & Erkek & $50+$ & Ortaokul & Emlakçılık & Emlakçı \\
\hline K13 & Erkek & $65+$ & illkokul & Emekli & Yerel halk & K29 & Erkek & 50 & Lise & Emlakçılık & Emlakçı \\
\hline K14 & Erkek & $65+$ & illkokul & Emekli & Yerel halk & K30 & Kadın & 29 & Lisans & Emlakçılık & Emlakçı \\
\hline K15 & Erkek & 65 & illkokul & Emekli & Yerel halk & K31 & Erkek & 55 & Ortaokul & Emlakçılık & Emlakçı \\
\hline K16 & Erkek & 57 & illkokul & Çiftçi & Yerel halk & K32 & Erkek & 62 & İlkokul & Emlakçılık & Emlakçı \\
\hline
\end{tabular}


karmaya başladığı ve elde ettiği parayı kısa sürede tüketerek maddi anlamda zor bir duruma düştüğü belirlenmiştir. Özellikle Mahmudiye Köyü'nde 10-12 hane dışında elinde toprak kalan ailenin kalmadığı ve çoğu ailenin topraklarını satarak, parasını değerlendiremediği tespit edilmiştir. Bu ailelerden bir kısmının sattğı arazi üzerine yapılan sitelere bekçi olarak çalışthğı belirlenmiştir. Okuyucu (2016) ikinci konut turizmi üzerine yapmış olduğu araştırmasında, Çınarcık (Yalova) ilçesinde tarım sektörünün ve tarımda çalışan faal nüfusun (\%53) yerini turizm ve hizmetler sektörüne bırakmaya başladığı tespit edilmiştir.

\section{Veri ve Yöntem}

Araştırmanın amacı, ikinci konut turizminin kıyı alanlarında yer alan zeytin arazileri üzerindeki baskısını ve arazi kullanımını ne yönde etkilediğini belirlemektir. Araşttrma, nitel araştırma yönteminde yapılmış, görüşme tekniği çalışmada kullanılmıştor. Görüşme yapılan kişi sayısı, veri doygunluğu ve çeşidinin sağlanmasına (bilginin tekrar etme durumuna) kadar devam etmiştir (Tablo 1). Araştırmada görüşme yapılan katılımcılar olasılıklı (rastlantısal) olmayan amaçlı örneklem yöntemine göre belirlenmiştir. Görüşmeler ses kaydına alınmış, daha sonra Microsoft World programına aktarılarak MAXQDA 12 programında çözümlenmiştir. Programın sol ara yüzünde oluşturulan kategoriler (kodlar) altına, sağ ara yüzdeki görüşme metninden alıntlamalar yapılmıştır. Görüşme 4 kategorik başIıkta temalaştırılarak analiz edilmiştir. Burhaniye Belediyesi'nden araştırma alanı arazi kullanımı ile ilgili kurumsal veriler temin edilmiştir. Landsat uydu görüntüsü ile araştırma sahasının 1990 ve 2017 yıllarındaki arazi kullanım verileri oluşturularak arazi kullanımındaki değişim görülmek istenmiştir. Araştırmada elde edilen tüm veri seti betimsel olarak analiz edilmiştir. Araştrrma soruları: Ikinci konut turizmi ile tarım arazilerinin kullanımı arasında nasıl bir ilişki vardır, ikinci konut turizmi zeytin arazileri üzerinde nasıl bir etkide bulunmaktadır? İinci konut turizminin arazi kullanımına olan etkisi yerel halk ve diğer paydaşlar tarafindan nasıl algılanmaktadır?

\section{Bulgular}

\subsection{Araştirma Alanı}

Araştırma alanı olan Pelitköy, Ege Bölgesi'nde yer almakta olup Asıl Ege Bölümü'nün Edremit Yöresi sınırları içerisinde kalmaktadır (Şekil 1). İdari olarak ise, Balıkesir İli'nin Burhaniye İlçesi'ne bağlı bir mahalledir. Pelitköy iki ayrı yerleşim biriminden oluşmaktadır: Köy yerleşim alanı ve sahilde yer alan ikinci konut yerleşim alanı. Köy yerleşim alanı, deniz kıyısından yak-

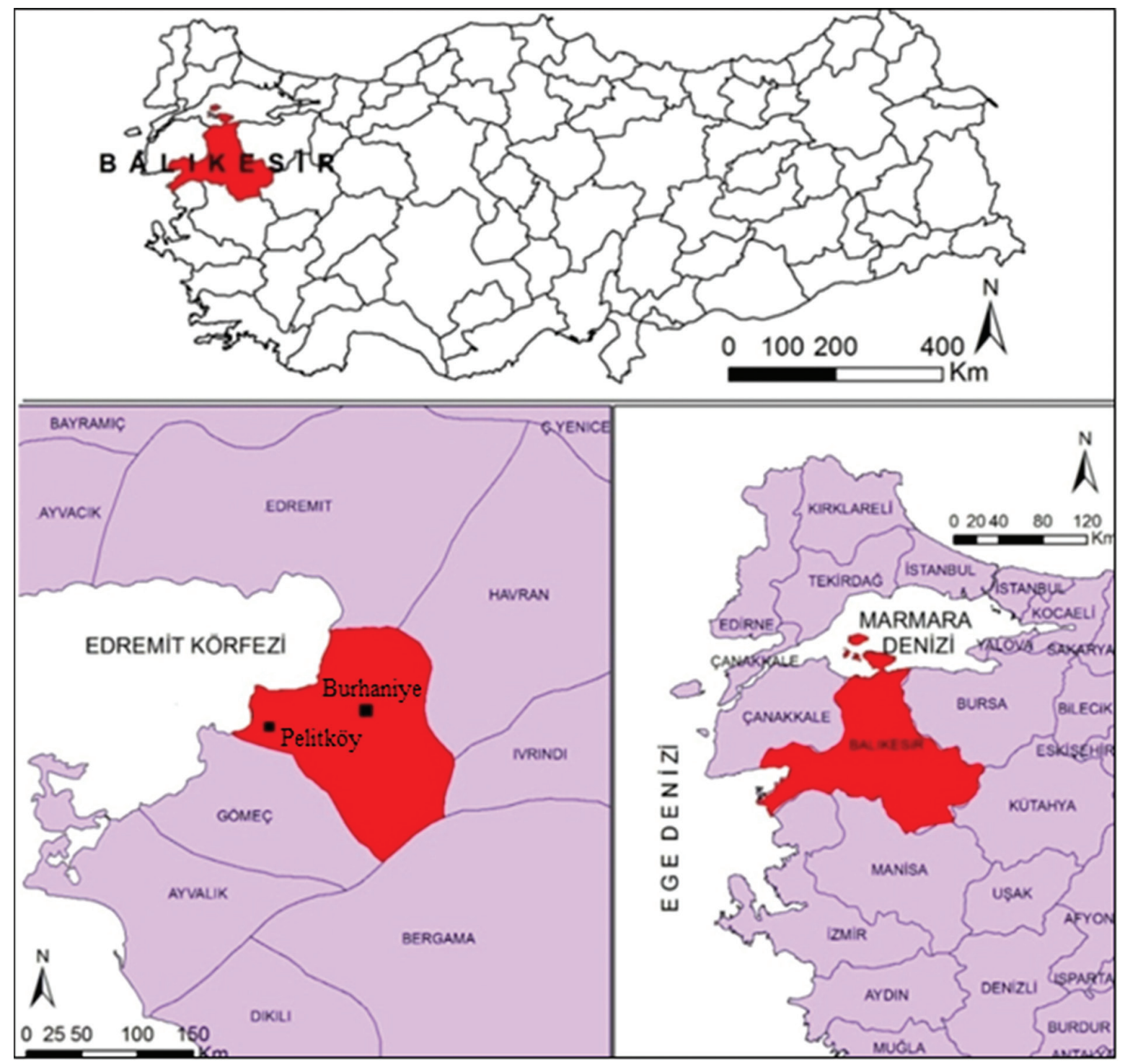

Şekil 1. Araştırma Sahasının Lokasyonu

Figure 1. Location of the research area 


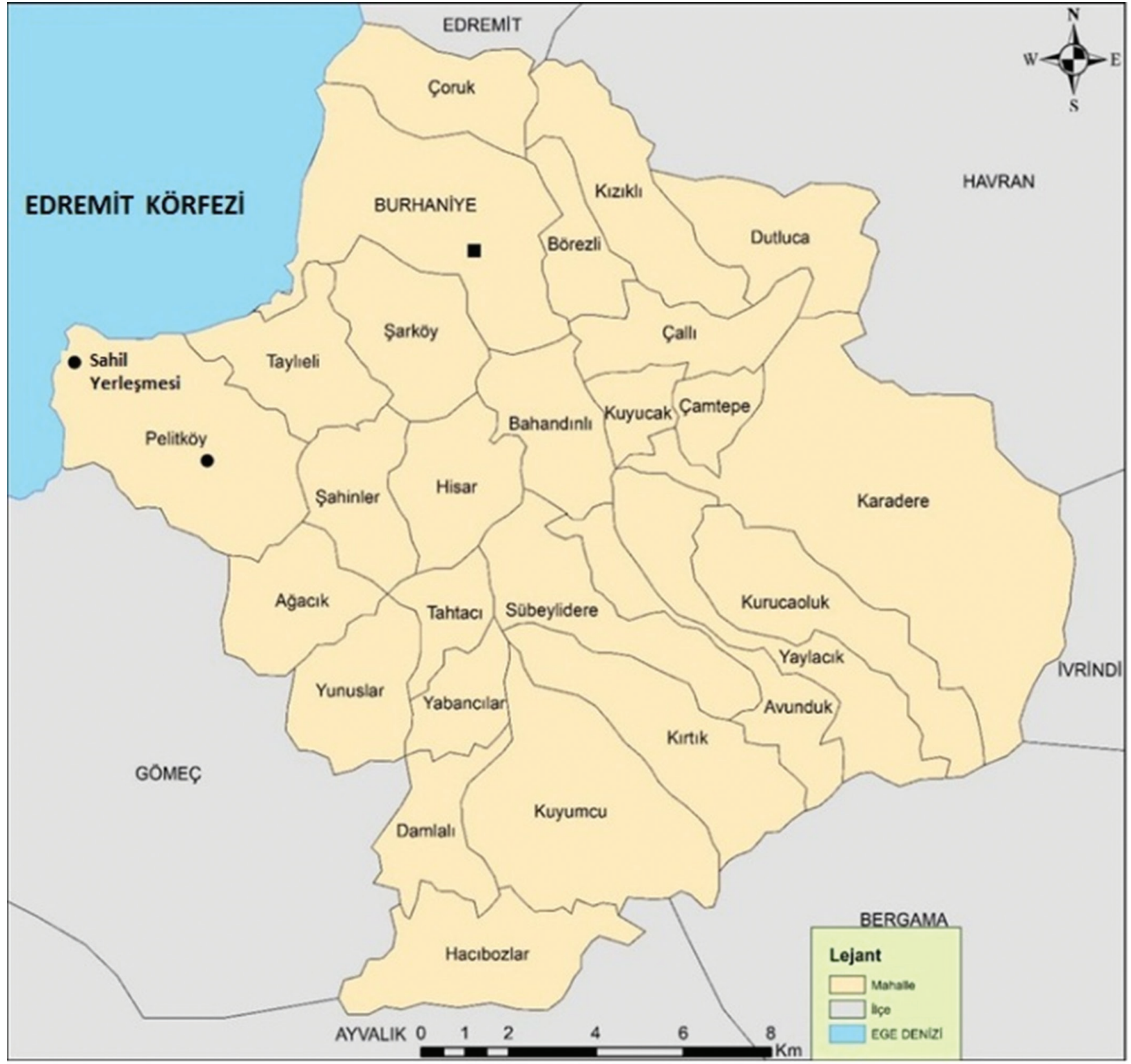

Şekil 2. Burhaniye İlçesinin Mahalleri

Figure 2. Neighborhoods of Burhaniye district

laşık 4 km içeride yer almaktadır. Pelitköy'ün Burhaniye ilçe merkezine olan uzaklığı ise yaklaşık 14 km'dir. Daha önceleri köy yerleşmesi olan Pelitköy, 1972 yılında belediye örgütüne (Pelitköy Belediyesi) kavuşarak belde yerleşmesi olmuştur. 2014 yılında Balıkesir ilinin büyükşehir olmasıyla birlikte, Pelitköy Belediyesi kapatlarak Burhaniye ilçe merkezine bağı bir mahalle (Pelitköy Mahallesi) olmuştur (Şekil 2). Pelitköy (yerel halkı) nüfusunun 2018 yılında toplam 2478 kişi olduğu tespit edilmiştir. Pelitköy temelde zeytin tarımı ile uğraşmakta ve ürettiği zeytinlerden zeytinyağı elde etmektedir. Pelitköy içerisinde 5 zeytinyağı fabrikası bulunmaktadır. Diğer bir ifadeyle, Pelitköy'de temel ekonomik faaliyet zeytin tarımıdır. Ancak Pelitköy'de yaşayan Romanların tarım arazileri bulunmamakta; Romanlar, kış döneminde zeytin bahçelerinde gündelikçi (yevmiyeci) olarak, yaz sezonunda ise sahildeki ikinci konut sitelerinde temizlik, bekçilik ve bahçıvanlık gibi vasıfsız işlerde sezonluk olarak çalışmaktadır.

\subsection{Araştırma Alanında Arazi Kullanımı}

Pelitköy kıyı alanı, 1980'lerden itibaren ikinci konut turizmi için yerleşmeye açılarak rekreasyon ve turizm faaliyetlerine konu olmuş; kıyı alanları kentli nüfusun yaz dönemlerinde kullanımına açılmış; bu durum sonucunda, ikinci konut yapılaşması ve altyapı çalışmaları ile arazi kullanımı önemli ölçüde değiştirilmiştir. Bu duruma Tablo 2 üzerinden baktığımızda, Pelitköy'ün toplam arazi varlığı 2910 hektar (29.109.157 $\mathrm{m}^{2}$ ) olduğu, en yoğun arazi kullanımının tarıma ayrıımış olan zeytin alanları $(\% 81,3)$ olduğu görülmektedir. Tarım ve zeytin alanlarından sonra alandaki en yoğun arazi kullanımının \%13 oranıyla sahil yerleşim (ikinci konut) alanı olması ise dikkat çekmektedir.

Tablo 2. Pelitköy'de Arazi Kullanımı (2017-2018) Table 2. Land Use in Pelitköy (2017-2018)

\begin{tabular}{|l|r|r|r|}
\hline Arazi Dağılımı & \multicolumn{1}{c|}{$\mathbf{m 2}$} & Hektar & \multicolumn{1}{c|}{$\%$} \\
\hline Köy içi yerleşim alanı & 1.243 .891 & 124,3 & 4,3 \\
\hline Sahil yerleşim alanı (ikinci konut) & 3.804 .431 & 380,4 & 13 \\
\hline Tarım ve zeytin alanı & 23.666 .935 & 2366 & 81,3 \\
\hline Orman & 393.900 & 39,3 & 1,4 \\
\hline Toplam & 29.109 .157 & 2910 & 100 \\
\hline
\end{tabular}

Kaynak: Burhaniye Belediyesi 
LandSat uydu görüntülerinden elde edilen verilere göre araştırma alanının arazi kullanımını değerlendirecek olursak: Şekil 3 ve 4'te görüldüğü üzere, araştırma alanında arazi kullanımının 1990-2017 yılları arasında önemli ölçüde farklılaştğı görülmektedir. Sahil kenarında 1990 yılında zeytin arazisi ve ikinci konutların iç içe olduğu, ikinci konutların sahil kenarındaki arazilerde bir yağ lekesi gibi dağıldığı görülmektedir.

Şekil 4'te görüldüğü üzere, 2017 yılında sahil kenarının ikinci konutlarla 1990 yılına göre daha fazla işgal edildiği görülmektedir. Arazi kullanımındaki bu değişim iki şekilde ifade edilebilir: Bunlardan ilki, zeytinlik alanlarının yerini ikinci konutlara bırakması, diğeri ise tarım alanı olarak görülen arazilerin zeytinlik alanına dönüştürülmesidir. 1990 yılından 2017 yılına kadar sahil kenarındaki zeytinliklerin kesilerek ikinci konutların

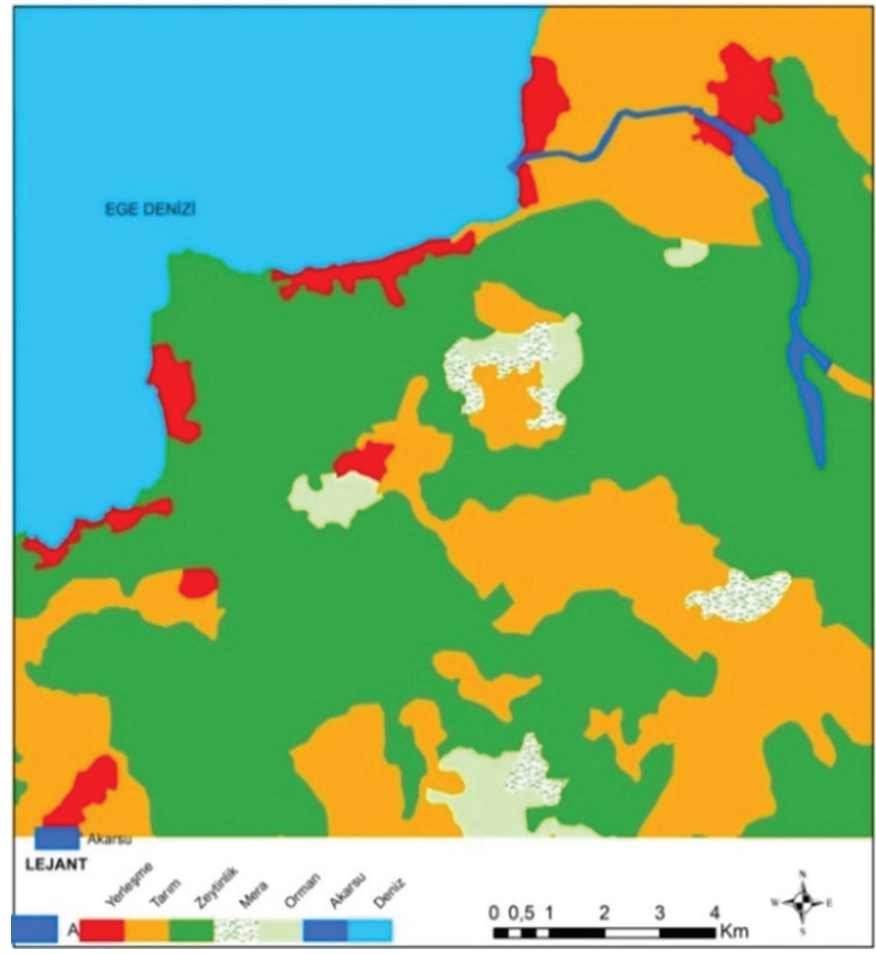

Şekil 3. 1990 Yılı Arazi Kullanımı

Figure 3. Land Use in Pelitköy in 1990 inşa edildiği söylenebilir. Ancak bunun yanında, belirtilen süre içerisinde zeytinlik alanların genişlemesi, yerel halkın sahil gerisindeki alanlara sürekli yeni zeytin ekmesi ile açıklanabilir. Tablo 3'ten de görüleceği üzere, 1990 yılında sahil yerleşmesinin (ikinci konut alanlarının) \%4,22'lik bir araziyi kapladığı, ancak mekânsal olarak büyümesi sonucu 2017 yılında bu oranın \%7,57’ye kadar yükseldiği görülmektedir. Tarım ve mera alanlarında azalma görülürken, yerleşme ve zeytinlik alanlarda bir genişleme görülmektedir. Zeytinlik alanlardaki genişleme, yukarıda ifade edildiği üzere, mera ve orman alanlarına doğru olan genişlemedir. Diğer bir ifadeyle, mera ve orman alanlarının zeytinlik olarak kullanılmaya başlamasının bir sonucudur (Şekil 5).

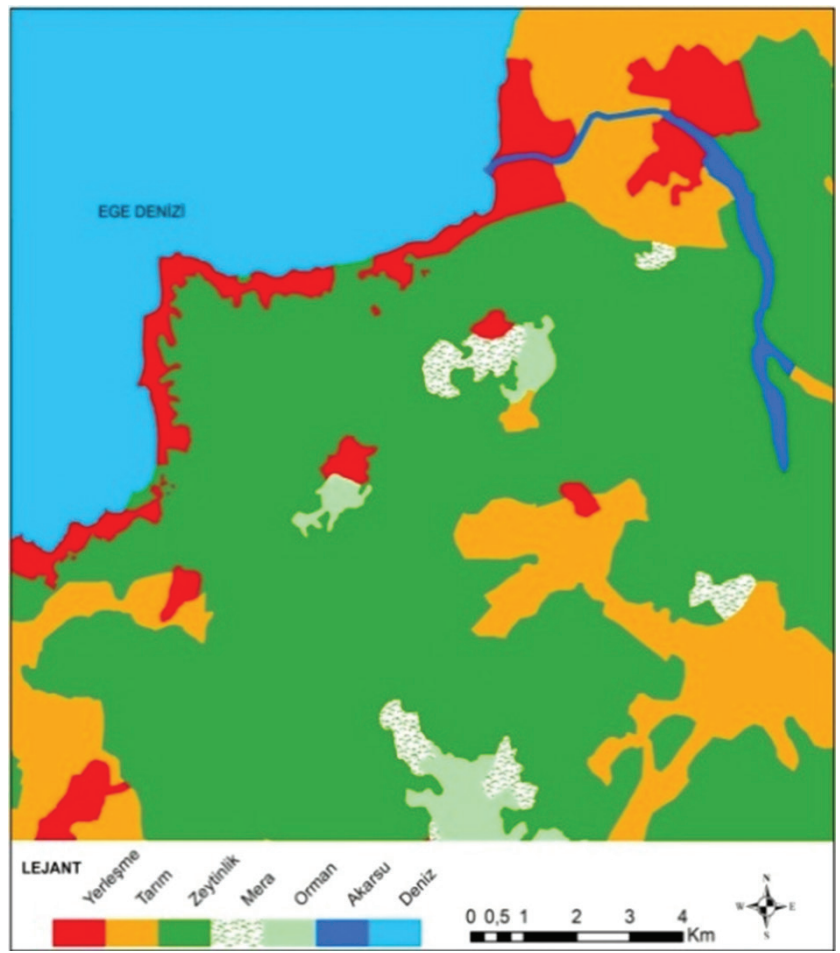

Şekil 4. 2017 Yılı Arazi Kullanımı

Figure 4. Land Use in Pelitköy in 2017

Tablo 3. 1990 ve 2017 Yıllarında Pelitköy'de Arazi Kullanımı

Table 3. Land Use in Pelitköy in 1990 and 2017

\begin{tabular}{|l|r|r|l|r|r|}
\hline & \multicolumn{2}{|c|}{1990 Yılı } & \multicolumn{3}{c|}{$\mathbf{2 0 1 7}$ Yılı } \\
\hline Yerleşme sahil & 755,963094 & Yüzde \% & & Hektar Alan (ha) & Yüzde \% \\
\hline Yerleşme köy & 34,004101 & 4,22 & Yerleşme sahil & 1359,914465 & 7,57 \\
\hline Tarım & 5618,958502 & 0,19 & Yerleşme köy & 45,1982 & 0,25 \\
\hline Zeytinlik & 10516,02569 & 31,30 & Tarım & 3354,852192 & 18,66 \\
\hline Mera & 434,517795 & 58,59 & Zeytinlik & 12228,74521 & 68,00 \\
\hline Orman & 378,266808 & 2,43 & Mera & 135,195495 & 0,75 \\
\hline Akarsu & 211,669006 & 2,10 & Orman & 598,319757 & \\
\hline Toplam & 17949,405 & 1,17 & Akarsu & 260,924194 & 3,32 \\
\hline
\end{tabular}

Kaynak: Landsat Uydu Görüntüsü 


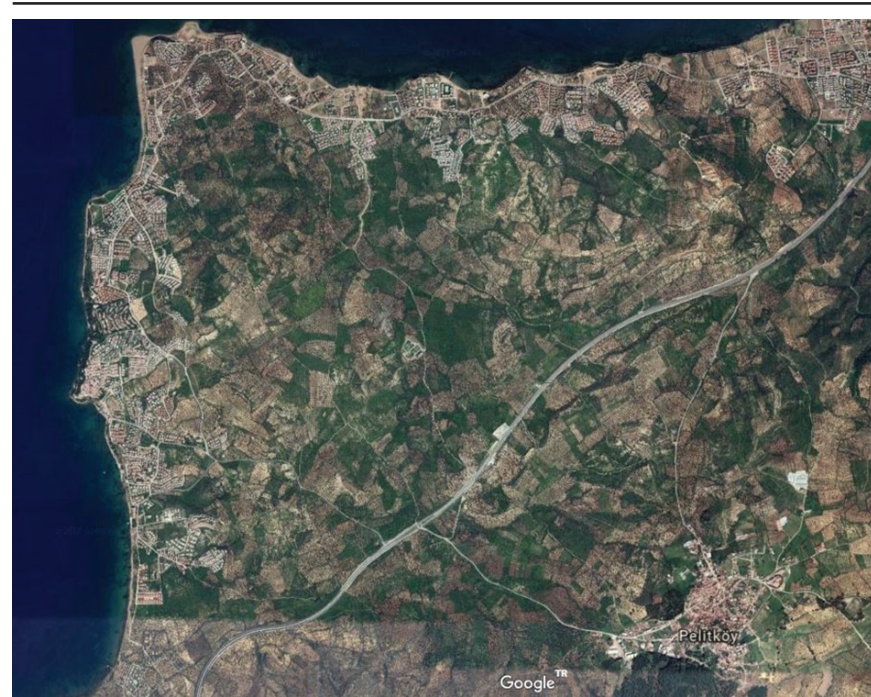

Şekil 5. Araştırma Alanı Google Earth Görüntüsü (Web 1).

Figure 5. Satellite Image (Google Earth) of Research Area

\subsection{Görüşmelere İlişkin Bulgular}

İkinci konutların zeytin alanları üzerindeki etkisine ilişkin paydaş görüşleri 4 kategorik başlık altında temalaştırılmıştır. Görüşme bulguları, kıyı kullanımının geleneksel kullanımından nasıl çıktı̆̆ ve nasıl bir kentsel arazi değeri kazandığının anlaşılması bakımından önemli sonuçlar vermektedir.

\section{Kategori 1: Yatırım Amacı Olarak İkinci Konutlar}

İkinci konutların tatil (dinlenme, eğlenme) amaçlı olarak satın alınması temel motivasyon olsa da bu konutlar geleceğe yönelik bir yatırım aracı olarak da görülmektedir. Bu durum, arsa ve konutların alınıp satlarak metalaşmasını beraberinde getirmektedir.

Insanlar arsa almaya çekinirler, zeytinlik almaya çekinirler, ama ikinci konut yatırımlık olarak daha mantklıdır. Örneğin Pelitköy'de 200 bin liraya aldığın bir eve 20-30 bin lira masraf yapıp, seneye o evi 300 bin liraya satılığa sunabilirsin. ...Zamanında bir yeri 30-40 bin liraya almışlar şimdi 300-350 bin lira istiyorlar (K30).

Pelitköy'ün görsel peyzaj ve konum olarak uygun olması dışardan gelen talebi her geçen gün artırmaktadır. İmar izni verilmiş saha içerisine yeni konut inşa edilecek alanın sınırlı olması, mevcut konutların daha çok değer kazanarak piyasasının yükselmesine neden olmaktadır.

...Buradakiler geneli emekli. Düşük geliri olan pek zannetmiyorum. Ben mesela emekli maaşımla aldım burayı. Şimdi burayı alamazsın o zamanki para ile şimdi en az 300 bin lira (K2). Sen yerini satacan diyor yani (devlet). Yoksa o yerler satılır mı yav. O satanlar pişman şimdi. O zaman üç liraydı şimdi oradaki bir ev servet. Eskiden 10 bin lira verdin mi sahilden istediğin yeri (zeytinliği) alabiliyordun, şimdi 100 milyar veriyorsun alamıyorsun orasını. Şimdi milyarlar konuşuyor orada (K22).

Son dönemlerde müteahhitler tarafindan bireysel olarak, alanda ikinci konutların yapılmakta olduğu alanda yapılan gözlemlerde belirlenmiştir. Nitekim alanda yaşayan yazlıkçıların da bu gelişmelerden haberdar olduğu görülmektedir.
Buradaki konutların çoğu eski, hepsi kooperatifle kurulmuş 1520 yıllık konutlar, ama arada yine yapılmaya başlandı. Saçma sapan yerlerde, kaldıramayacağınız tarzda rant alanına dönüştürmeye çalışıyorlar (K5).

Burhaniye içerisindeki sermaye sahiplerine ek olarak, dışarıdan gelen arsa spekülatörleri ve alsatçılar, arsa ve emlak piyasasındaki hızlı değer artışını kendileri için uygun bir kâr ortamına dönüştürmektedirler.

2-3 sene evvelîsi 70-80 bin liraya satılmayan araziler şimdi 200-250 liraya satilıyor. Araziler, evler değil. ...150 bin liraya (ikinci konut) bulamasın artik. 600 bin liraya kadar var Pelitköy sahilinde. ...200 bin 300 bin liraya satılan (yazlık) evler, eski evler (K28). Imara açılmayan gerideki zeytinlikleri alsatçılar topladı, değerlenecek diye, imar genişleyecek diye (K11).

Sahildeki ikinci konutların gerisindeki tarım alanları (zeytinlikler), ileriki dönemlerde imar izninin iç kesimlere doğru genişleyebileceği düşüncesiyle, dışardan gelen alsatçılar ve bölgedeki sermaye sahipleri tarafindan satın alınmaya başlandığı belirlenmiştir. Başka bir ifadeyle, oluşan talebe karşı sahile yakın çok sayıdaki zeytinliğin yerel halk tarafindan satışa sunulmaya başlandığı görülmektedir.

Şimdi zeytin mahsulünü gelir yaptrrıp da zeytinlik alma işi durdu. Şimdi zeytin ağacını alan insanlar dışarıdan Istanbul'dan geliyor. Parası bol. Parası bol olunca benim 100 bin lira vereceğim yere 150 bin lira veriyor alıyor. Imara açılmamış yerleri de alıyorlar. Mesela $2 \mathrm{~km}$ ötede tepeden denizi görüyorsa alıyorlar. Bunlar da yatırım. Buralar denizi görüyor diyor, ilerde buralar para yapar diyor. Adamın 1 trilyon parası varsa 200 bin lirasını atıveriyor oraya (zeytinliğe) (K20). Zaten şimdiden yol kenarları imara açılacak diye dönümü 100 bin liraya 200 bin liraya, bazı yerlerde 400-500 bin liraya çıkt dönümü, 1000 $\mathrm{m}^{2} \mathrm{si}$. Asfalt kenarlarında. Niye? ... beklenti var (K31). Sahil şimdi emlakçıların alışveriş merkezi gibi bir yer oldu. Alsatçıların zenginlerin yatırım aracı oldu. Sahilin yüzde 10'u ancak açıldı imara. Yatırıma da bu umutla alıyor, yarın imara girer de kar edebilir miyim diye. ...5 kere 10 kere alınıp satlan yerler var sahilde. Alıyor 50 liraya, her zaman kaybeden ilk sahibidir. Bugün için iyi bir fiyattan veriyor, ama ertesi yıl daha çok para yapıyor yer. Sahilde bir dönüm yer 10 lira ise burada (köyde) 2 lira 3 lira ...imara yakın yerleri (zeytinlikleri) çoğu kişi sattı zaten. Alan da yatirım olsun diye alıyor, paraya sıkısınca o da 50 bin lira fazlaya başkasına satıyor (K24).

Araştırma alanında sahile yakın çok sayıda zeytinlik internet üzerinden satışa sunulmuştur. Aktif olarak arama yapıldığında 184 arsa/zeytinliğin satışa çıkartıldığı görülmektedir. "Pelitköy'de imarlı arsa", "Pelitköy'de deniz manzaralı arsa", "Pelitköy'de imar sınırına yakın arsa" şeklinde çok sayıda ilanın internet üzerinden verildiği görülmektedir (Fotoğraf 1). Burhaniye ilçesindeki emlakçıların bir kısmı, imar sınırının iç kesimlere doğru genişletilmesinin tarım arazilerinin ekonomik değerini yükselteceğini ve yerel halkın bu durumdan yararlanabileceğini düşünmektedir. 


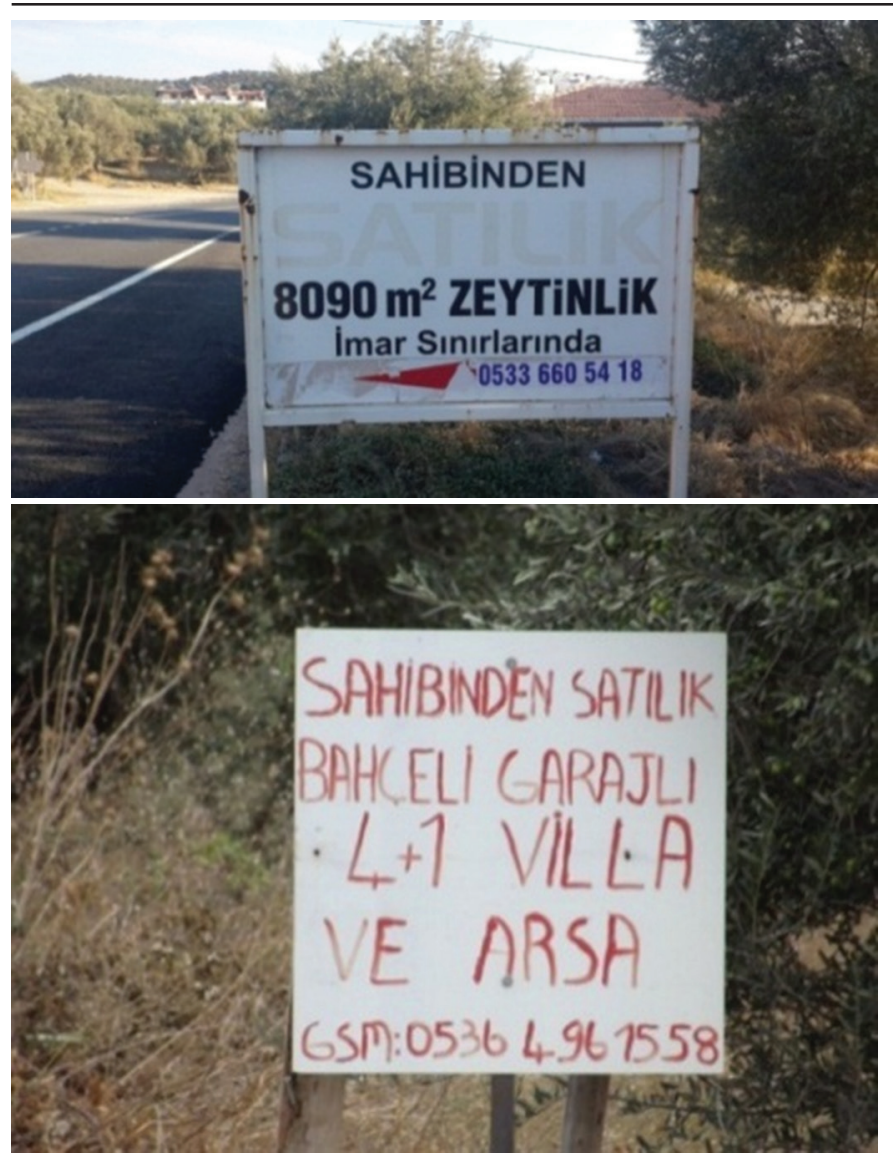

Fotoğraf 1. Pelitköy'de zeytinlik ve ikinci konut ilanlarından görseller (Ceylan(C)

Photo 1. Images of olive garden and second homes, for sale

Buraya imar gelirse 5 liralık arazi 50 liraya çıkarsa bu köylü vatandaşın arazisi yükselecek rant sağlayacak. Şimdi benim yerim bin lira, imara girerse beş bin lira olacak. ...Öbür türlü (imara açılmazsa) arsalar devamlı yükselir. Bin liraya satılan arsanın metresi 2 bin liraya çıkar bir sene sonra, (imara) açılmadığı zaman (K28).

\section{Kategori 2: İkinci Konutların Çevresel Etkileri: Betonlaşma}

İkinci konut turizminin doğal ortam üzerine olan en temel çevresel etkisi (betonlaşma) yapılaşmadır (Foto 2). Sahil kenarlarına inşa edilmiş ikinci konutlar alanın kırsal dokusunu bütünüyle değiştirmiştir. Başka bir deyişle, arazi kullanım durumunda belirttiğimiz üzere, alanda tarımsal peyzajın yerini büyük ölçüde kaybettiği, 1990 yılı sonrasında kıyı bandında ikinci konutların ana peyzaj karakterini oluşturmuştur. Tarım deseni 1990 sonrasında yerini ikinci konut desenine bırakarak kıyı alanının ana peyzaj karakteri değişmiştir. Kesilen zeytinliklerin yerini binalar, asfalt yollar ve altyapı donatiları (kanalizasyon, elektrik, su, internet vb.) almıştır.

1980'lerde ilk siteler yapılırken büyük hatalar yapıldı, zeytin kıyımı oldu. Sonra daha az oldu kıyım. Iskele Mahallesi-Ayvalık arası komple boş arazisi idi. Çıplak arazi hep zeytinlikti (K23). ...Sahil gittikçe betonlaşt,, daha da betonlaşacak, ayağımızı uzatacak toprak kalmadı. Zaman gelecek şu köylü denize de giremeyecek (K15).
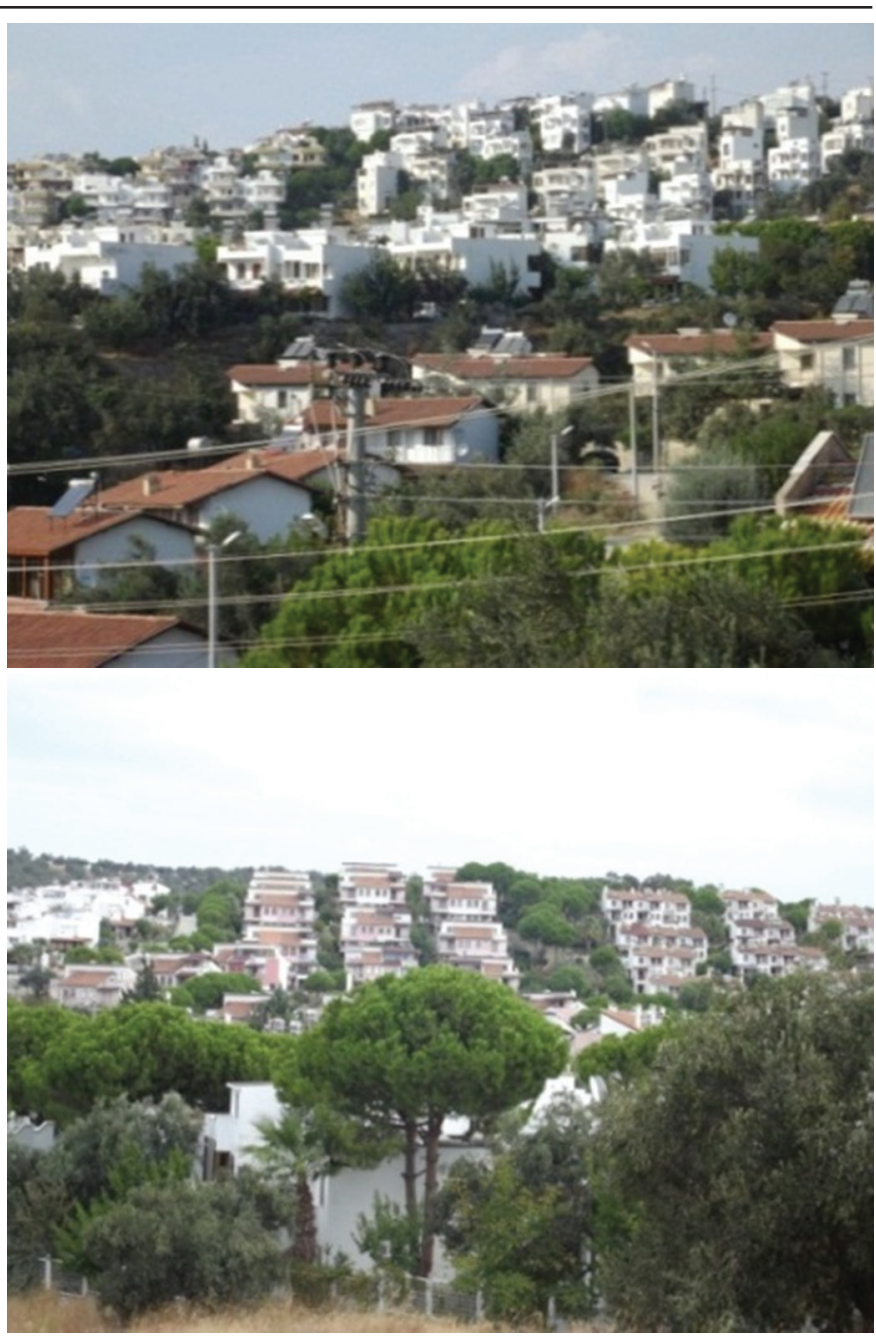

Fotoğraf 2. Zeytin alanlarına inşa edilmiş ikinci konutlardan görseller (Ceylan (C)

Photo 2. Second homes built on olive garden

İkinci konut sakinleri konutlarda ve bahçede birtakım onarım (tadilat) çalışması yapmakta, çıkan enkazın yol kenarına ve zeytinliklerin arasına dökmektedirler. Bu durum, çevrenin kirlenmesine neden olduğu ve zeytinliklere zarar verdiği için yerel halk tarafindan eleştirilmektedirler.

(Yazlıkçılar) evinin inşaatını yaptırıyor, evinin enkazı kalıyor, getiriyor yola atyor fayansları. Onun bunun arazisine götürüp atyyorlar (K23). Yazlık evler yüzünden arazimiz gitti. Köy arazilerinin hemen hemen üçte biri gitti. Çöplerini bile zeytinliklerin arasına döküyorlar. Poşetleri bile atyyorlar zeytinliklere (K17). Valla gelen yazlıkçılardan hiç memnun değilim. Hiç gelirleri yok yani. Buraya gelenler hep zeytini katlediyorlar (K12). Köye fazla bir şeyi yok aşağının (sahilin). Bizim de burayı daralttyorlar. Her geçen gün zeytin ağacı yok oluyor. Yazlıkçıların hiçbirisinin faydası yok. Evin yapılacağı yerdeki zeytinleri söktüler. Bahçede bir tane zeytin ağacı kaldıysa kaldı. Yazlıkçılar geldi mi kendi bahçesini korur, senin benim malımı korumaz. ...Zeytin ağaçları bitti yani. ... Köye hiçbir katkıları yok zarardan başka... (K15).

Alanda görüşme yapılan emlakçılar, zeytinliklerin kesilmesiyle doğaya zarar verildiğini, bu nedenle zeytinliklerin korunması gerektiğini düşünmektedirler.

Ben zeytinliklerin yazlık eve dönüşmesini istemem. Ağacı tamam kesip atmıyorlar söküp başka bir yere dikiyorlar, onu 
biliyoruz ama sonuçta onu oradan kaldırıyorlar, böylece betonarme oluyor. Pelitköy bence zeytinlik olarak kalmalı o bölge (K30). Zeytinliklere yazlık ev yapılmasın. Zeytinlikler dursa daha iyi. Zeytinlikler kesiliyor ağaç yapılıyor. Zeytinlikler yeşil gittiği zaman her şey kötü oluyor. Genelde rantçılar oraları talan ediyor. Rantçılar Ankara'dan istanbul'dan geliyor. ...Dağın eteğine yazlık yapmışsın. Teleferikle mi aşağı incen. Darmadağın ediyor çevreyi. ...Zeytinliklerin de sonuna kadar korunması gerekiyor bence. Zeytinlikleri bir fabrikaya bir sanayiye açmak mantıklı değil (K9). En çok ekmek yediğim Pelitköy halkı, el değiştiriyor, alıyoruz satıyoruz, satışa aracı oluyoruz. Ama yazık edilmiş bir doğa parçası (K32).

Araştırma alanı sahilinde görülen bir diğer çevresel etki, yeraltı sularının aşırı ve bilinçsiz kullanımıdır. İkinci konut siteleri içerisine (ruhsatlı ve ruhsatsız olarak) açılan sondaj kuyularının aşırı kullanılması yeralt su rezervlerinin azalmasına neden olmaktadır. Yeraltı su tablasının düşmesi, deniz suyunun yeralt suyuna karışma riskini artırmaktadır. Sondaj (kuyu) suyu ile site bahçesinin (çiçek, çim, ağaç vb.) sulanması, tozmaması için toprak yolun sık sık sulanması, özel araçların site önlerinde yıkanması durumlar, yeraltı suyunun aşırı kullanımına neden olmakta ve rezervini etkilemektedir.

Yeralt suyunu ben de kullanıyorum. Tabiî ki ruhsatını alıyorsan kullanıyorsun. Genelde ruhsatı değil kuyular, ama ben yasaları bildiğim için daha temel atılmadan ben ruhsatımı aldım (K7).

Araştırma alanı kıyılarında altyapı eksiklikleri ya da atık işletme tesislerinin tam kapasite çalışamaması nedeniyle zaman zaman denize atık suların karışması ve çevreye kanalizasyon kokusunun yayıldığı belirtilmektedir.

Biz de bazen arıtma taşıyor denize. Kanalizasyonlar yapılırken iyi yapılmadığı için zaman zaman kanalizasyonun suyu nasıl oluyorsa şu ileriden taşıyor denize. O gün hiç kimse denize girmiyor kokuyu duyunca. Sonra telefon açıyorlar, Balıkesir Belediyesi'nden geliyorlar orayı tamir mi ediyorlar ne yapıyorlarsa gidiyorlar. Bence kanalizasyon yapılırken bir hata. ...Bu kanalizasyonda da bir hata var yani (K8)....Kanalizasyonda sorun yok. Denizimiz çok temiz. Zaten bir sorunumuz olan ORCAM var, ORCAM da şu an denize girilmez. Kendini bilenin girmemesi lazım. Sebebi de Havran'dan gelen bir çay var dere, bütün pisliği bize akıyor, ama o da bu sene arıtma tesisi yapılmaya başlandı, seneye biter. O sorun da çözülecek. Bir tek sorunumuz o (K27).

Sahile kurulan semt pazarında akşamları temizlik yapılmadığı ve bu nedenle koku ve sinek fazlalaşması olduğu belirtilmektedir. Ayrıca çöp konteynerlerinin olmaması nedeniyle yol kenarlarındaki belirli noktalara yığılan çöplerin koku kirliliğine neden olduğu ifade edilmektedir.

Adam getirmiş geri dönüşüm kutusunu yolun kenarına koymuş. Sahil kenarında hiç olacak bir şey mi? Adamlar onu çöp kutusu olarak kullanıyor, niye kullanıyor? Çöpü atacak bir yer olmadığı için. Bu büyük bir problem yani. Çarşamba günü pazar kuruluyor, akşam (çöplerin) kabasını süpürmüşler sabah 11 de yıkamasını yapıyorlar. Öğlene kadar sineği de konuyor başka bir böceği de konuyor. Kokudan pislikten geçilmiyor. Adam kirazını atmış, domatesini atmış olduğu gibi yere yapışmış (K10).

\section{Kategori 3: Zeytin Politikaları: Kesilen Zeytinlikler...}

Genelde tarıma özelde ise zeytin yetiştiriciliğine yönelik belirli dönemlerde geliştirilen ve uygulanan politikalar, zeytin üretimini ve zeytinliklerin alansal büyüklügünü etkilemektedir. Deniz (sahil) kenarlarına imar izninin verilmesi, zeytin tarımı üzerine yapılan en büyük politikalardan birisi olmuştur. Çıkarılan bu politikalar sonucu yapılan uygulamalar, zeytinliklerin imara açılmasını, kesilmesini ve yerlerine ikinci konut yapılmasını hızlandırmıştır.

Burası 1972'de belediye oldu. 1990-1992 yıllarında başladı sahil (inşaat). Onca zeytin ağacı harap verap oldu gitti. Söktüler kesitler bina yaptılar. Deniz kenarına kadar zeytin ağaçları vardı hep gitti. Çok zararı oldu, o ağaçlar kolayla yetişiyor mu evlat, yıllar alıyor (K13). Güzelim zeytinlikler kesildi, kökleri söküldü. Yav binlerce ev yapıldı. Her birinin olduğu yerden ikişer beşer ağaç sökülse hesap et (K14). Bir sürü konut yapıldı. Bu zamana kadar bir sürü zeytin ağacı sökülmüşs. Kendilerinin siteleri yapılırken zeytin sökümüne sesini çıkarmıyorlar, şimdi yeni konut yapacaklara zeytinleri kesmeyin diyorlar. Sen kestin de yaptın ya. Kendi sitelerinde zeytinlikler sökülürken seslerini çıkarmıyorlar, bu seferde diyorlar zeytin ağaçları kesiliyor. Sen siteyi yaparken zeytin ağaçlarını kesiyorsun ya. Hep menfaate dayalı yani (K16). Şimdi satılacak parmakla gösterilecek kadar az yer var yani. Ovamı kalmadı tarım arazimiz bitti yani (K26). ...Tabi ağaç kaybı olmuştur inşaat alanlarında. Ama sayı olarak bilemeyeceğim. ...Kesilen yerler de var. Bazı siteler engel olmayan zeytin ağaçlarına ellememiş. Engel olanları vermiş dumana, kökünden (K11).

İkinci konutlar inşa edilirken zeytinliklerin kesilmesi yerine sökülerek başka bir yere tekrar dikilmesi gerçekleştirilmiş olsaydı, daha çevreci bir uygulama olacağı ifade edilmektedir. Nitekim kesilen asırlık zeytin ağaçlarının yeni (genç) ağaçlara göre daha verimli olduğu belirtilmektedir.

Yazlık evler zeytinlikleri ortadan kaldırdı, hep kestiler. Öyle ağaçlar vardı ki iki yüz kilo zeytin yapıyordu. Güzel güzel ağaçlarımız gitti yazık yani. Ne yapacakmış, ev yapacakmış. Zeytinliklerin kesilmesine ben karşıyım. Inşaat betonlaşmasına ben karşıyım. Ben karşıyım bu milli servet. Bu doğal mal. Beton yığınından bi fayda yok bize o ağaçlardan fayda var bize. ... Ucuz gitti o zamanlar buralar (zeytinlikler). Dee 30 sene önceden yer satıldı buralarda. 30 seneyi geçti hatta. Yazık oldu o ağaçlarımıza, çınar gibi ağaçlara (K18). Zeytinin geleceği bunlar başta olduğu sürece kötü. Zeytinleri yok etmeye başladı idareciler. Firmaları zengin edecek, zeytinliği yok edecek. Şu kadar zeytin diktik diyorlar, ama dünya kadar da zeytin gidiyor. 100 yıllık ağacı kesiyorsun yerine yeni ağaç dikiyorsun. O da kurumazsa 10 yıl sonra ürün vermeye başlar. Hazır zeytin ağacı varken onunla ilgili (koruma) yasa çıkartın meclisten. Imara açılan yerlerin önüne geçemiyorsun. En az yüzde 10 zayiat ile yapılaşmaya açılıyor zeytinler. Sahilde zeytinler o şekilde gitti. Belediye ilk zamanda imara açarken zeytinler kesilmesin şart getirseydi olurdu. Hep para gelsin de nasıl gelirse gelsin hesabı (K21).

İkinci konut sakinleri ve emlakçılar, tarımın ve doğanın geleceği için çevrenin korunması gerektiğini belirtmektedirler. 
...(zeytinliklere yazlık konut yapılması) yazık günah çok acıyorum çok üzülüyorum. Tarihte yerini bulamadılar, nasıl ekildi nasıl gelişti. Ama vuruyoruz kırıyoruz, yakıyoruz kesiyoruz, ama üzülüyorum. Elma melma kes onu yeniden yetiştiriyorsun ama zeytinin yetişmesi çok zor, zeytine kıyılmaması lazım, ama yapılıyor, belediye de izin veriyor. ... Her şey de para olmuş. Çocuklarımızın geleceği torunlarımızın geleceğini düşünmezsek vur kes yap, ev-konut yap ver (K6). Zeytinlik alanların böyle yazlık turizme bilmem neye açılması kötü. Ha yapılacaksa da düzenli bir plana göre, bir imar planına göre yapılmalı, koruyarak yapılmalı. ...Şurada bir yer yapıldı, şu tepenin orda, komple tıraş, ondan sonra ne ağaç var ne gölge var, hiçbir şey yok (K9). Bence artık böyle kalması lazım. Bundan sonra da yazlığa hiç gerek yok yani. Hükümetin gündeminde imara açma gibi bir şey var biliyorsunuz, ama bence gerek yok yani. Yeteri kadar yazlık olduğuna inanıyorum ben Türkiye'de. Şu an kıyılardaki zeytinlikler durmalı. Zeytinler büyük bir nimet yani, Allah'ın bir lütfu yani, gerek yok fazlasına. ... Emlakçılar tabi işin şimdi para yönüne bakar yani, ama bu işin birazcık insani boyutu da var ya da tarımsal yönü diyelim. Bunu da düşünmek lazım. Para para da nereye kadar yani (K29).

Yerel halkın ve ikinci konut sakinlerinin zeytinliklerin korunmasını istediği sahildeki işletmeciler tarafindan da ifade edilmektedir. Başka bir deyişle, zeytin alanlarının alansal daralmasının insanlardan dolayı olmadığı, oluşturulan politikalar ve çıkarılan yasalardan kaynaklandığı belirtilmektedir.

Buradaki insanlar duyarlı zeytinliklere karşı. Mesela her yazlığın önünde zeytinlik vardır, kimse o zeytini koparmaz, kesmez. Herkes duyarlıdır. Ama işte politika molitika olur da hani zeytinlikler imara açılırsa o zaman tamam. Bak, buranın ekmeği zeytindir. Insanlar ekmeğini zeytin ağacından elden edilen üründen sağlıyor, zeytinyağı. Keser mi insanoğlu, kesmek istemez. Yazlıkçılar ve köylü dâhil zeytinliklerin korunmasını istiyor. Kimse meyve veren ağacı taşlar mı taşlamaz. ...Burhaniye Pelitköy sahilinde zeytinsiz bir alan yok, ama imara açtı̆ınız her yerde zeytin kesiliyor (K25).

3573 Sayılı Zeytin Koruma Kanunu 1939 yılında çıkartılmış, belirli dönemlerde yasada çeşitli düzenlemelere gidilmiştir. 1995 yılında bu yasada yapılan değişiklikte, "zeytin alanlarının 3 km mesafe yakınına zeytinyağı fabrikası hariç kimyasal atık, toz ve duman bırakabilecek sanayi tesislerinin yapılamayacağı ve işletilemeyeceği, zeytinlik alanların çeşitli sebeplerle daraltılamayacağı" ifadesi eklenmiştir. Bu yasayla zeytinliklerin sökülmesi Ziraat Odası'nın uygun görüşüne ve Bakanlık iznine bırakılmıştır. Zeytin Koruma Yasası ile alandaki zeytinliklerin son dönemlerde korunduğu da alanda belirtilmektedir:

...Şu an da durduruldu, Zeytin Koruma Kanunu burada çok güzel uygulandı. Pelitköy'de (sahilde) yapılaşma 20 yıl olmadı, neredeyse 3-4 senedir yeni yapılar yapılıyor. Zeytin Koruma Kanunu ve Kıyı Koruma Kanunu buranın aşırı yapılaşmasını önledi, korudu bölgeyi. Ama şimdi biliyorsun Zeytin Koruma Kanunu ikide bir Isıtıp getiriyorlar, durduruldu reddedildi. Sanayinin yapılacağı bölge vardır bir sürü boş arazilerimiz vardır, buradaki zeytinliği söküp sanayi yapabilir misin canım olur mu böyle saçmalık (K32).

3573 Sayılı Zeytin Koruma Kanunu'nun zeytin alanlarının ko- runması için getirdiği çeşitli kriterler nedeniyle yerel halkın kendi toprağını satamama gibi birtakım engellerle karşılaştığı ifade edilmektedir.

Şimdi bir kanun çıkarmışlar. Şimdi iki zeytinliğin arası 5 km den az ise zeytinliği satamıyorsun. Ben böyle saçmalık hayatta görmedim ya. Geçenlerde adam satamadı zeytinliğini yav. Adam ağlıyor yav, kendi tarlasını satamıyor. Müşterek tapu olursa satamıyorsun. Olacak iş değil yav. Yav bunlara kulak veren adam olması lazım. Bu muhalefetle bu milletvekilleri ile yürümez bu gitmez yav (K22).

3573 Sayılı Zeytin Koruma Kanunu üzerinde 2017 yılında yeni bir düzenlemeye gidilmek istenmiş ve mecliste bir çalışma başlatılarak yasa tasarısı hazırlanmıştır. Bu yasa teklifinde, "geçmişteki hukuksuz uygulamalarla zeytin alanı olarak bilinen yerlerdeki zeytin alanlarının kullanılmaz hale geldiği" gerekçe gösterilmiş, "Sanayi bölgesindeki zeytin alanlarının 3 km yakınına kadar asla hiçbir tesis yapılmayacak, $3 \mathrm{~km}$ sonrasında bu tesisler kurulabilmesi" yönünde yasa tasarısı hazırlanmıştr. Üstün kamu yararı ve ülkenin geleceği için belirli yerlerdeki zeytinlik alanlara sanayi tesisi yapma izninin verilmesi amaçlanmıştır. Çıkarılmak istenen bu yasa alandaki paydaşlar tarafindan endişeyle izlenmiş ve bu yasa nedeniyle paydaşların çeşitli tepkiler gösterdikleri görülmüştür:

...Mesela bi yasa çıkaracaklar, kime çıkaracaklar zengine çıkaracaklar. Fabrika yapacak liman yapacak, kesecek. Biz bunlara karşıyız. Bırakın bizim ağacı zeytini, değmeyin yani. Senin yaşın daha genç, 10 sene 20 sene sonra burayı böyle şey (boş alan) göremezsin, daha betonlaşmış görürsün. ...Zeytin ağaçlarının giderek kesileceğini düşünüyoruz. ...Eğer ki böyle işte limana ya da böyle çok fabrika yapmaya. Burası turizm kenti. Turistik kent. Burası Ege'nin incisi. Bozulmaması lazım. Böyle bir havayı başka bir yerde teneffüs edemezsin (K7)....(Politikacılar) masada zeytinyağını yalanı yalanı yerler. Tahrip etmeye gelince de tahrip edeceğiz diyorlar. Şuraya bir tane ağaç dikmiyor. Gördügün şu ağaç 100 yaşında mı 150 yaşında mı şu ağacı tahrip ediyorsun. ..Ben buna karşıyım evlat, ben sana açık konuşuyorum. Biz yeşile karşı değiliz. ...Orası değerli bir yer, ... Hükümete diyor ki (sanayici), sen bana burayı hemen kanun çıkar bana ver diyor, ben (sanayi tesisi) yapam da buradan para kazanayım diyor. ...3-5 tane kapitalist ülkenin dokusunu bile yok etmeye çalışıyorlar. Beni söyletme boş ver, beni sinirlendirme. ...Bizim (Başbakan) Binali de çıkmış konuşuyor: Zeytinler verimsiz imiş. ...sen masanda... yiyorsun verimsiz mi?. Bugün tarım bitti, saman yurt dışından geliyor, buğday yurt dışından geliyor. Türkiye bir tarım ülkesi yanlış anlama. Şimdi bu hükümetin amacı zeytini de bitirip zeytin de yurt dışından gelsin zeytinyağı da yurt dışından gelsin. Hükümetin projesi bu (K4).

Köylü sahildeki zeytinlikleri sattyor. Bir de şimdi devlet bir kanun çıkardı ya peşkeş çekecekler yani bu sahilleri. Mesela buraya olacak 100 tane ev, ortada da olacak bir işalanı yani. Ama geçen bastırdılar, muhalefet itiraz etti ya. Ama açık kalmış gene bu, ama bir iki sene sonra geçecek bu (yasa). O zaman burası gider bu sahil gider. Sahil imara açılırsa (Çanakkale-izmir yolunun) yolun alt komple gider. 100 tane ev olacak ortasında bir iş merkezi olacak (K19). Zeytinlik alanlar imara açılsa bir yandan iyi olur ama bunu çok iyi organize etmeleri lazım. Ama şimdi imara açtıkça zeytinleri kesiyorlar söküyorlar 
yok ediyorlar. Imara açılırsa pahalanır, fiyatlar yükselir zeytinliklerin. Açılmazsa zeytin korunmuş olur. ...Şimdi bi Zeytin Koruma Kanunu var. O kanun kapsamında koruma uygulaması yapılıyor, yeterli mi yeterli değil. Buralarda turizme bu kadar talep ve bu kadar da rant olunca zeytinlikler bi şekilde gözden çıkıyor (K31).

Araştırma alanındaki zeytinliklerin kesilmesine korumacı bir yaklaşımla bakmanın ötesinde, çıkarcı-firsatçı bir anlayışla bakan yerel halktan işletmecilerin de olduğu görülmektedir. Zeytinyağının para etmediği, zeytin ağaç sayısı ve zeytinyağı üretiminin azalması durumunda zeytinyağının daha çok gelir getireceği düşüncesi haklı gerekçeler olarak sunulmaktadır:

Zeytin ağaçları kesilsin, kesilsin. Niye kesilmesin, kesilecek. ... Ben zeytinciyim ben 10 bin ağaç ile uğraşıyorum. Ne oluyor, zeytin ne getiriyor, ama o yer 5 dönüm yer 200-250 bin liraysa imara girdiğinde 5 trilyon olacak. ... Kesilmeyip de ne olacak yani ne olacak yani. Yolun alt (sahil) kesilse ne olur kesilmese ne olur. ...Ben emlak yapıyorum diye oraya imar açılsın demiyorum. Ben zeytin üretiyorum, satamıyorum yağımı. Biraz önce 16 liradan yağ verdim (piyasa gidiş sabit 20 lira). Kesilmiyor da ne oluyor, kesilsin azalsın (yağ miktarı), daha çok paraya satalım yağımızı. Ne olacak kesilince (K28).

Alanda görülen çevresel etkiler bütüncül olarak düşünüldügünde, ikinci konut turizminin plansız gelişmesi, kıyıdaki konut yapılaşmasının zeytinliklerin kesilmesi üzerine temellendirilmiş olması ve dar alanda (site içinde) yoğun konut yapılaşmasının gerçekleştirilmiş olması çevresel etkilerin nedenleri olarak sıralanabilir. Başka bir deyişle, korumacı ve sürdürülebilir bir yaklaşımla kıyı planlaması yapılmış olsaydı, zeytinliklerin kesilmesi yerine sökülerek başka bir yere tekrar dikilmesi gibi uygulamalarla hareket edilmiş olsaydı ve iki konut arasındaki mesafenin daha uzak (seyrek dokuda) olması gibi ölçütler imar planına koyulmuş olsaydı alanda daha az çevresel tahribat görülebilecekti.

\section{Kategori 4: İkinci Konut Sakinlerinin Kıyı Alanıyla İlgili Algısı}

Araştırma alanın imar planında ikinci konutların sık aralıklı olarak düzenlenmiş olması, kıyıdaki yapılaşma yoğunluğunun en temel dinamiği olarak dikkati çekmektedir. İkinci konutların kooperatifleşmenin verdiği hızla site içerisinde $40 \mathrm{~m} 2$ aralıkla inşa edilmiş olması, dar alandaki yapılaşma yoğunluğunu göstermektedir. Konutların birbirine çok yakın inşa edilmesi, kıyı alanın kentsel bir yerleşme görünümü vermesine neden olmuştur. Başka bir anlatımla, kıyı imar planının hazırlanmasında konut mesafelerinin daha geniş tutulması sağlanamadığ için, dar alanda yoğun bir yapılaşma özelliği görülmektedir. Kıyıdaki bu yapılaşmaya ikinci konut sakinlerinin de tepki gösterdiği görülmektedir.

Aslında buraların imara açılmaması lazımdı. Doğal hali ile kalması lazımdı. Eskiden bir tek bu burun vardı, Artur denilen yer. Şimdi buralar 24 yıldır doldu bir beton yığını oldu. Ayvalık'tan gelirken yemyeşildi buralar. Tek bizim bu evler vardı. Şimdi buralar Karşıyaka Mezarlığı gibi görünüyor (K1).

Görüşme yapılan ikinci konut sakininin (K1) kıyı alanını Karşıyaka Mezarlığı'na benzetmesi, Fotoğraf 3'te görüldüğü üzere, alanın yoğun yapılaşma dokusu ile kentleşmeye doğru bir gidiş göstermesinin sonucudur.

Bu kadar yapılaşmadan şikâyetçiyiz. Doğallığı bozuluyor buraların. Dağı taşı yazlık yapmak gerekmiyor diye düşünüyorum. ileride yeşile hasret kalacağız, ağaçlara hasret kalacağız. ... Buralar betonlaşacak, kaygımız o. Ağaçlar kesiliyor yerine ev yapılıyor... Yani şu kıyıların işgal edilmesini, değiştirilmesini herhangi bir şey için dönüştürülmesini istemiyoruz. Böyle kalmalı, bakir kalmalı, dokunulmamalı. ...Burada on gün on beş gün kalacağım diye her yeri inşaat alanına harabeye çeviriyorlar. On beş günlük tatil için ev satın alınacaklar ülkesi değil burası (K3).

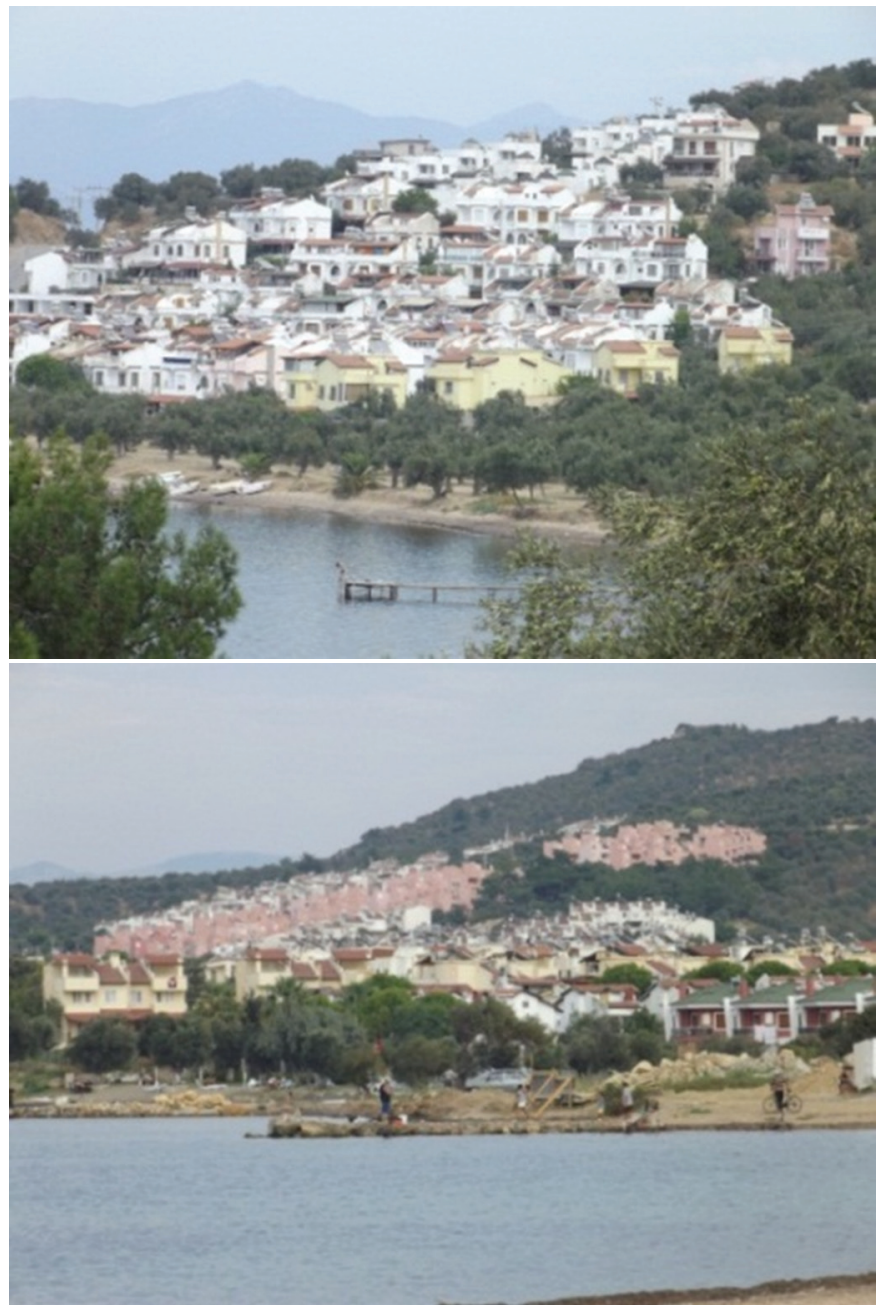

Fotoğraf 3. İkinci konut yapılaşmasından görseller (Ceylan@)

Photo 3. Second homes built in coast area of Pelitköy

Yukarıdaki ifadede ikinci konut sakininin (K3) araştırma alanında ortaya çıkan çevresel bozulmalardan yakınması, alanı sahiplendiklerinin bir göstergesidir. Benzer şekilde, alana ilk gelen ikinci konut sakilerinin sonradan gelenler yazlıkçılardan ve alandaki hızlı yapılaşmadan memnun olmadığı görülmektedir:

Biz buradan ev aldığımızda şu karşılarda hiç ev yoktu mesela. 2002'de oralarda hiçbir şey yoktu. Karşılara bak hep site. ... Taa o köşeye kadar hepsi yazlık, neden? Duyan geliyor, duyan geliyor. İstanbul'dan, Ankara'dan, Eskişehir'den, Izmir'den, her yerden gelen var, her yerden. ...Öyle bir zaman gelecek ki site yapmaya yer kalmayacak. Bak tamamen doldu yani (K5). 


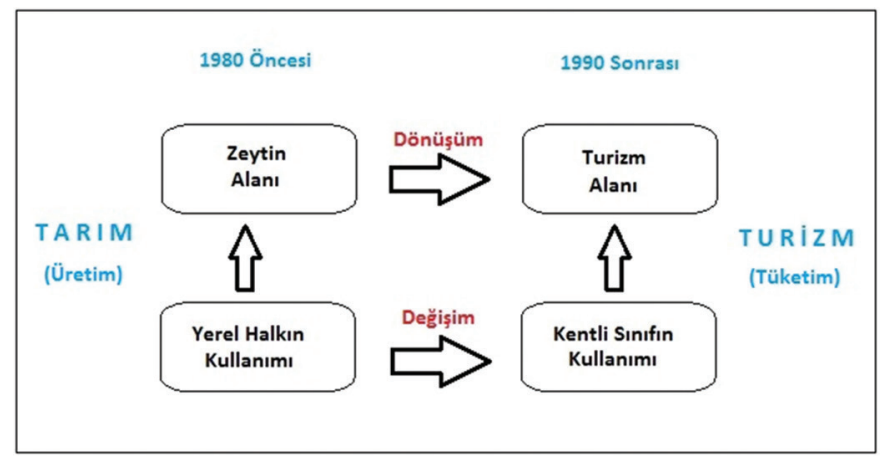

Şekil 6. Arazi Kullanımında Görülen Dönüşüm (Ceylan @)

Figure 6. Land use's transformation in Pelitköy

Şekil 6'tan da görüleceği üzere, Pelitköy sahilinin 1980 öncesinde tarım (zeytin) arazisi olarak kullanıldığı, ancak 1980 sonrası kıyıda görülen ikinci konut yapılaşması ile bir turizm alanına dönüştüğü görülmektedir. Başka bir anlatımla, daha önce bir tarımsal üretim (zeytin) alanı olan sahil kenarı, 1990 yılı sonrasında boş zaman ve eğlence amaçlı kullanılan bir tüketim mekânına dönüşmüştür. Sahil kenarında yer alan zeytinlik alanlara verilen imar izni ve kentli nüfusun turizm ve yatırım amaçlı talebinin ortaya çıkardığı kooperatifleşme, talebe karşı gelişen arz durumu, tarım alanı olarak kullanılan zeytin bahçelerinin yerini ikinci konutlara bırakmasına neden olmuştur. Daha önceleri boş ve bakir bir alan iken günümüzde beyaz boyalı ikinci konutların sahil kenarını adeta bir "mezarlık" görünüm verdiğini düşünülmektedirler.

\section{Tartışma}

1939 yılında çıkartılan 3573 Sayılı Zeytin Koruma Kanunu'na göre, zeytinlik arazilerin daraltılması yasaklanmıştır. Ayrıca bu kanunda, belediye sınırları içerisinde kalan zeytinlik sahalara yapılacak toplam yapılaşmanın (altyapı ve sosyal tesisler dâhil) zeytinlik alanların \%10'unu geçemeyeceği belirtilmiştir. Ancak 1980'lerde Pelitköy Belediyesi'nin sahile verdiği imar izinlerinin bu sınırı aşmış (Tablo 2) ve zeytinlik alanların kıyıda hızla daralmıştır. Sahile yapılmış 180 site içerisindeki ikinci konutların yaklaşık 40 metre aralıklı olarak inşa edilmiş olması, kıyı imar planı hazırlanırken zeytin ağaçlarının korunmasının göz ardı edildiğini göstermektedir. Kıyı alanındaki bu yoğun yapılaşmayı (betonlaşma), kentleşmeye doğru bir gidişin olduğunu işaret etmektedir. İmar sınırının genişleyeceği beklentisi ile imar sınırına yakın zeytinliklerin köylüden satın alınması, köylünün topraksız kalmasına ve üretici pozisyonunu kaybederek kırsalda yoksullaşmasına neden olmaktadır. 2017 yılında tartşılan "zeytin yasa tasarısı" ile zeytinliklerin endüstriyel kullanıma açılması yerine, bu kaynakların çıkarılacak kanunlarla sıkı bir şekilde koruma altına alınması gerekmektedir. Aksi durumda turizm ve endüstriyel baskılar nedeniyle bu kaynakların korunması mümkün olamayacaktır.

\section{Sonuç}

Araştırma alanı kıyıları, 1980'lerden itibaren ikinci konut turizmi ile bir dönüşüme uğramıştr. Kıyı alanının geleneksel (tarımsal) kullanımı kentli nüfus tarafindan turizm amaçlı olarak değiştirilmiştir. Kıyı alanlarındaki tarım arazilerinin (zeytinliklerin) ikinci konut turizmi için kullanılması, tarım toprağının alansal olarak daralmasına, kıyı dokusunun değişmesine neden olmuştur. Devlet müdahalesi (teşvik ve imar izni) ile turiz- me konu olan kıyı alanındaki zeytinliklerin turizm baskısı altında kalması, arazi kullanım amacının değişmesine ve tarımsal mülkiyetin el değiştirerek yerini arsa mülkiyetine bırakmasına neden olmuştur. Arazinin kullanım amacının değişmesinin yanında, kullanıcısı da değişmiştir. Başka bir anlatımla, zeytin alanlarından boş zaman tüketim mekânına doğru kırsal peyzaj yeniden yapılanmış, köylünün üretim için kullandığı tarımsal arazi kentli nüfusa geçerek tatil (tüketim) amaçlı olarak kullanılmaya başlanmıştır.

Araştırma alanındaki bu değişim ve dönüşümler, Woods'un (2005) da vurguladığı gibi, tarım amaçlı geleneksel kullanımdan kentli nüfusun turizm ve rekreasyon amaçlı olarak tükettiği bir mekana dönüştürülmüştür. Marsden (1998b) ve Holmes'in (2006) literatürde ifade ettiği, "kırsalda tarımın baskın gücünü kaybetmesi ve bunun yerini turizmin alması" durumu, araştırma alanı kıyılarında da görülmektedir. Kıyıdaki imarlı arazilerin, ikinci konutların ve zeytin bahçelerinin ekonomik değerinin artması ve kısa zaman içinde birçok kez alınıp satılması alanın metalaştırıldığını göstermektedir. Pelitköy'de görülen bu durum, literatürde (Marsden 1998a, Woods 2005, Perkins 2006, Crouch 2006, Overvag 2009, Uryy 2015) tartş̧ılan "kırsal alanların metalaştırılması ve dönüşümü" ve "yeni kırsal coğrafyanın oluşturulması" durumu ile örtüşmektedir.

Pelitköy kıyı alanında arazide görülen değişimler, Alpaslan ve Ortaçesme'nin (2009) yaptıkları çalışmada, Side Manavgat kıyılarında tarım ve ormanlık alanların daralması, buna karşılık otel ve ikinci konut alanlarının genişlemesi sonucu ile de benzerlik göstermektedir. Ayrıca Kanat ve Demir'in (2008) Sapanca köylerindeki araştırmasında, köylülerin kentten gelen yazlıkçılara topraklarını satarak toprağını elinden çıkarmaya başladığı ve elde ettiği parayı kısa sürede tüketerek maddi anlamda zor bir duruma düşme durumu Pelitköy yerel halkında da görülmektedir. İkinci konut turizminin Türkiye'nin farklı bölge ve yörelerinde benzer sonuçlar doğurduğu görülmektedir.

Araştırma alanı olan Pelitköy'de zeytin en önemli bir değerdir, bu yüzden zeytinin korunması gerekmektedir. Diğer bir ifadeyle, zeytin araştırma alanı ile bütünleşik bir değer olup zeytin alanlarında koruma kullanma dengesi gözetilmelidir. Araştırma alanında zeytincilik kırsal toplumun temel geçim kaynağı niteliğindedir. Bu nedenle, tarımsal faaliyetlerin sürdürülebilirliğini sağlamak için, geçmişte ikinci konut inşası için yapılmış olan zeytin ağacı kıyımının tekrarlanmaması, mevcut ağaçların korunması gerekmektedir. Koruma politikaları oluşturmadan ve koruyucu yasa ve planlamalar yapılmadan kıyı alanındaki zeytinliklerin geleceğe taşınmasını sağlamak güç olacaktır. Bu nedenle daha güncel ve sert yasal düzenlemeler yapılmalı, sanayi ve turizm uğruna tarımsal kaynak değerler (zeytinlikler) alansal olarak daraltılmamalıdır. Koruma önlemlerinin alınmaması ve 3573 Sayılı Zeytin Koruma Yasası'nın esnetilmesi durumunda, araştırma alanının denize bakan zeytinliklerinin ikinci konutlarla işgal edilmesi kaçınılmaz olacaktır. Benzer şekilde, araştırma alanı içinden geçen Çanakkale-İzmir karayolunun her iki tarafinda yer alan zeytinliklerin sanayi tesisine açılması söz konusu olacaktır.

Araştırma alanında zeytin alanlarının amacı dışında kullanılmasına izin verilmemeli, zeytinlik alanlar alansal olarak küçültülerek parçalanmamalı, ikinci konut siteleri içinde kalan 
zeytinlikler site sakinleri üzerine zimmetlenerek ağaçların korunmasından ve yaşatımasından bu kişiler sorumlu tutulmalı ve bu ağaçların izinsiz kesilmeleri durumunda site sakinlerine para cezası ve adli takip yapılabilmelidir. Pelitköy'de tarım alanlarının korunmasında sivil toplum örgütlerinin oluşturulması ve bu örgütlerin Pelitköy yerel halkını bilgilendirmesi ve bilinçlendirmesi de sağlanmalıdır. Oluşturulacak STK'lar ile katı ve sıvı attkların alandaki etkilerini izleme, bu atıkların toplanması ve alandan uzaklaştırılmasını izleme gibi denetlemeler gerçekleştirmesi sağlanabilir. Başka bir deyişle, STK'lar Pelitköy kıyı alanını denetleyebilmeli ve kontrol edebilmelidir. Alanın ekonomik sürdürülebilirliğini sağlamak için ise; yerel halkın tarım toprağını elden çıkarmasının (mülksüzleşmesinin) önüne geçilmeli ve halkın tarımsal üretimini devam ettirmesi sağlanmalı, kırsal yaşanabilirlik için çiftçi kredilerinin düşük faizli ve uzun vadeli olarak yeniden planlaması yapılmalıdır. Aksi durumda, topraksız kalan Pelitköy halkının kırsaldan kopuşu ve şehre göç ederek vasıfsız işlerde çalışarak marjinalleşmesi kaçınılmaz olacaktır.

Araştırma alanı kıyılarında yeraltı sularının sürdürülebilir kullanımı sağlanmalı, entegre doğal kaynak yönetimi kıyılarda uygulanmalı, korumacı ve sürdürülebilir bir yaklaşımla kıyı planlaması yapılmalıdır. Yapılacak planlamalarda tarımsal peyzajın bozulmasının önüne geçilmeli, kıyılardaki yapılaşma (betonlaşma) yoğunluğu denetim altına alınmalıdır. Gelecek nesillere bırakılacak tarımsal kaynaklarının yok edilmesinin önüne geçilerek gıda güvenliği (tarımda sürdürülebilirlik) sağlanmalıdır. Sonuç olarak; planlama olmadan yapılan turizm faaliyetleri, tarım arazilerinin bilinçsizce kullanılmasına neden olmakta ve sürdürülebilir olmayan bir yaklaşımla tarım arazilerinin hızla tüketilmektedir. Tekeli'nin (2016: 65-67) ifade ettiği üzere, kırsal alanların tarım topraklarında karlılık tek belirleyici ölçüt olmaktan çıkarılmalı, biyolojik çeşitlilik korunmalı ve geliştirilmeli; doğal, biyolojik ve tarımsal kaynakların sürdürülebilirliği sağlanmalıdır. Bu anlamda, kıyı alanları için yapılacak politikalarda, turizm ve endüstriyel amaçlı politikaların tarımsal alanları etkilemesinin önüne geçilmelidir. Turizm ve endüstri sektörü kıyılarda kendine yer açmak için, zeytinliklerin yeniden imara açılma riskinin ortadan kaldırılması ve daha korumacı ve sürdürülebilir bir yaklaşımla hareket edilmesi gerekmektedir.

\section{Kaynakça}

Akova, S. (2019). Türkiye Kıyı Alanlarında Nüfusun Değiş̧imi ve Kıyı Alanlarına Baskılar, İçinde (Ed. S. Üçışık-Erbilen, G. Şahin) Beşeri ve iktisadi Coğrafya Araştırmaları. İstanbul: Eski Babil Yayınları, 149-182.

Akyarlı, A., Yüksel, Y., Çevik, E., Yalçıner, A.C., Güler, I. (2002). Kıyı Bölgesi Yönetimi ve Sorunları, Türkiye Mühendislik Haberleri, 420-421-422 (4-5-6): 65-68.

Alpaslan, A. Ö., Ortaçeşme, V. (2009). Side-Manavgat Kıyı Kesimi Alan Kullanımlarının Kıyı Planlaması ve Yönetimine Yönelik Değerlendirilmesi, Akdeniz Üniversitesi Ziraat Fakültesi Dergisi, 22 (2): 169-178.

Arkon, C. (1989). Turizm ve İkinci Konut Politikalarının Çevresel Etkileri, II. Ulusal Bölge Planlama Kongresi, İstanbul: İÜ Mimarlık Fakültesi Baskı Atölyesi: 75-81, İstanbul.

Bahar, O., Kozak, M. (2005). Turizm Ekonomisi. Ankara: Detay Yayıncllık.

Bakırcı, M. (2007a). Türkiye'de Kırsal Kalkınma: Kavramlar-Politikalar-Uygulamalar. Ankara: Nobel Yayıncılık.
Bakırcı, S. (2007b). Yabancıların ikinci Konut Talebinin Fiziksel Çevreye Etkisi: Dalyan Örneği, Yayımlanmamış Yüksek Lisans Tezi, Gazi Üniversitesi, Ankara.

Birol-Özerk, G. (2012). Türkiye'de Yazlık İkinci Konutların Yarattı̆ı Sorunlar Bağlamında Balıkesir ili Ege Kıyılarındaki Yazlık İkini Konutlara Genel Bir Bakış, MEGARON Balıkesir Mimarlar Odası Balıkesir Şubesi Dergisi, Temmuz: 29-35.

Butler, R. (1998). Rural Recreation and Tourism, Inside (Ed: B. Ilbery) The Geography of Rural Change. Pearson, Prentice Hall, Harlow, pp. 211-232.

Cheshire, L. (2006). Governing Rural Development: Discourses and Practices of Self-Help in Australian Rural Policy. Alsershot: Ashgate Publishing.

Cloke, P. (1993). The Countryside as Commodity: New Rural Spaces for Leisure, Inside (Ed: S. Glyptis) Leisure and the Environment: Essays in Honour of Professor. J.A. Patmore, London and New York: Belhaven Press, 53-67.

Crouch, D. (2006). Tourism, Consumption and Rurality Inside (Eds: P. Cloke, T. Marsden, P.H. Mooney) Handbook of Rural Studies. London: SAGE, 355-364.

Çelik, K. (2015). Kıyı Alanlarının Planlanmasına Kıyı Kenar Çizgisinin Önemi, Küresel Mühendislik Çalışmaları Dergisi, 2 (1): 36-43.

Dal, N., Baysan, S. (2007). Kuşadası'nda Kıyı Kullanımı ve Turizmin Mekânsal Etkileri Konusunda Yerel Halkın Tutumları, Ege Coğrafya Dergisi, 16: 69-85.

Duru, B. (2003). Kıyı Politikası, Kıyı Yönetiminde Bütünleşik Yaklaşımlar ve Ulusal Kıyı Politikası. Doktora Tezi, Ankara: Mülkiyeliler Birliği Vakfi Yayınları Tezler Dizisi 13.

Doğaner, S. (2001). Türkiye Turizm Coğrafyası. İstanbul: Çantay Kitabevi.

Emekli, G. (2008). Kuşadası Turizminin Talep ve Pazar Potansiyelinde Yaşanan Değişimler, Geçmişten Geleceğe Kuşadası Sempozyumu II (4-9 Kasım 2008) Bildiriler Kitabı, Kuşadası, s.1-14.

Floysand, A., Jakobsen, S. E. (2007). Commodification of Rural Places: A Narrative of Social Fields, Rural Development and Football. Journal of Rural Studies, 23, 206-221.

Güney, I.., Somuncu, M. (2018). Kuşadası İlçesinde Turizmin Yaşam Döngüsü: Mekânsal ve Toplumsal Öğeler Üzerinden Bir Değerlendirme, Türk Coğrafya Dergisi, 71: 101-116.

Güzer, C. A. (2010). Kaçan Bir Fırsat: Port Alaçat, Ege Mimarlık, Ocak: 29-31.

Halfacree, K., Boyle, P. (1998). Migration, rurality and the post-productivist countryside, Inside (Eds: P. Boyle, K. Halfacree), Migration into Rural Areas: Theories and Issues. John Wiley \& Sons, Chichester, 1-20.

Halfacree, K. (2006). Rural Space: Constructing a Three-Fold Architecture, Inside (Eds: P. Cloke, T. Marsden, P.H. Mooney) Handbook of Rural Studies. London: SAGE, 44-62.

Hall, D., Mitchell, M., Roberts, L. (2003). Tourism and the Countryside: Dynamic Relationships, Inside (Eds: D. Hall, L, Roberts, M. Mitchell) New Directions in Rural Tourism. Ashgate, Aldershot, 3-15.

Halseth, G. (2004). The Cottage Privilege: Increasingly Elite Landscapes of Second Homes in Canada, Inside (Eds: C.M. Hall, D.K. Müller), Tourism, Mobility and Second Homes. Between Elite Landscapes and Common Ground. Toronto: Channel View Publications, 34-54.

Holmes, J. (2006). Impulses towards a Multifunctional Transition in Rural Australia: Gaps in the Research Agenda. Journal of Rural Studies, 22: 142-160.

Ilbery, B. (1998). Dimensions of Rural Change, Inside (Eds: B. Ilbery) The Geography of Rural Change. Harlow: Pearson Education, 1-10.

İdil, B. (1989). Kıyı Kentlerimizin Yok Olan Kimlikleri ve Düşündürdükleri: Trabzon Özelinde Bir İrdeleme, Mimarlık, Sayı: 234 (2): 94-95.

Kanat, M., Demir, M. T. (2008). Sapanca Köylerinde Kırsal Yapının Değişimi, İstanbul Üniversitesi Coğrafya Dergisi, 16: 60-79. 
Kara, H. (1984). Mersin-Erdemli Arasında Gelişen Deniz Turizmi, Tarım Alanları ilişsisi ve Sorunları, Türkiye Coğrafya Dergisi, 3: 141160.

Keshavarznia, N., Sarvar, R., Mahdavi, M. (2013). Environmental Impacts of Second Home Development on Damash Village in Gilan Province, Iran, International Journal of Engineering and Advanced Technology (IJEAT), 3 (2): 181-184.

Kızılgün, Ö. (2001). Prospects for Eco-Planning Approach in Rapidly Changing Coastal Areas: The Case of Eastern Antalya Region. Unpublished PHD Thesis. METU, Ankara

Koç, H., Seymen, Ü. (1995). Ege Kıyılarında Tatil Konutu Olgusu, Planlama Dergisi, 95 (1-2): 25-31.

Kurt, S. (2015). Bursa Kıyılarında İkinci Konut Yapılaşmasının Kıyı Jeomorfolojinse Etkisi, Turkish Studies, 10 (2): 641-662.

Marsden, T. (1998a). New Rural Territories: Regulating the Differentiated Rural Spaces. Journal of Rural Studies, 14 (1): 107-117.

Marsden, T. (1998b). Economic Perspectives, Inside (Eds: B. Ilbery) The Geography of Rural Change. Harlow: Pearson Education, 13-30.

Marsden, T. (1999). Rural Futures: The Consumption Countryside and its Regulation, Sociologia Ruralis, 39 (3): 501-526.

Mizan, G. (1994). Turizm ve Ikinci Konut Gelişiminin Doğal Çevre Üzerindeki Etkilerinin Incelenmesi: Dilek Yarımadası ve Yakın Çevresi Örneği. Yayımlanmamış Yüksek Lisans Tezi, iTÜ, İstanbul.

Murdoch, J., Lowe, P., Ward, N., Marsden, T. (2003). The Differentiated Countryside. London: Routledge.

Mukul, i., Sarı, S. (2015). Türkiye'de Dönüşüm Mekânı Olarak Kentler: Kentsel Dönüşüm, Uluslararası Sosyal Araşttrmalar Dergisi, 8 (39): 893-922.

Müller, D. (2005). Second Home Tourism in the Swedish Mountain Range, Inside (Eds: C. M. Hall, S. Boyd) Nature-based Tourism in Peripheral Areas. Development or Disaster?. Clevedon: Chanel View Publication, 133-148.

Okuyucu, A. (2016). Ikinci Konutların Ekonomik ve Sosyo-Kültürel Etkileri Konusunda Bir Araştırma: Yalova-Çınarcık Örneği. Yayımlanmamış Doktora Tezi, Ankara Üniversitesi, Ankara.

Overvag, K. (2009). Second Homes in Eastern Norway, Unpublished PhD Thesis, Norwegian University of Science and Technology. Trondheim.

Özkan, B. (1993). Rekreasyonel Amaçlı Konutsal Yapılaşmaların Güney Ege Kıyı Peyzajına Etkileri Üzerinde Araştırmalar, Turizm Yıllığı. Turizm Bankası A.Ş., s.133-140.

Perkins, H.C. (2006). Commodification: Re-Resourcing Rural Areas, Inside (Eds: P. Cloke, T. Marsden, P.H. Mooney), Handbook of Rural Studies. London: SAGE, 243-257.
Salihoğlu, G., Gezici-Korten, F. (2016). Turizm Sektöründe Gıda Tedarik Coğrafyasının Analizi: Alanya Örneği, Coğrafi Bilimler Dergisi, 14 (2): 89-105.

Samırkaş, M., Bahar, O. (2013). Turizm, Yoksulluk ve Bölgesel Gelişmişlik Farklııkları. Ankara: Detay Yayıncılık.

Sertkaya-Doğan, Ö. (2011). Silivri'de Turizmin Gelişmesi: Sorunlar ve Çözüm Önerileri, Doğu Coğrafya Dergisi, 16 (25): 89-102.

Sesli, F. A., Aydınoğlu, A.Ç., Akyol, N. (2003). Kıyı Alanlarının Yönetimi. Türk Mühendis ve Mimar Odaları Birliği Harita ve Kadastro Mühendisleri Odası 9. Türkiye Harita Bilimsel ve Teknik Kurultayı Bildiriler Kitabı, (31 Mart-04 Nisan 2003), s. 757-768, Ankara.

Seymen, Ü. B., Koç, H. (1996). Türkiye'de Kıyı Yerleşmelerinde Tatil Konutları. Başbakanlık Toplu Konut İdaresi Başkanlığı, Konut Araştırmaları Dizisi: 17, Ankara.

Somuncu, M. (1996). Kayseri'de Bağcılık, Ankara Üniversitesi Coğrafi Araştirmalar Dergisi, 12: 107-133.

Sönmez, M. A. (2013). Gaziantep'te Özelliklerini Yitiren Geçici Bir Yerleşme Şekli: Bağ Evleri, Asia Minor Studies, 1 (2): 129-148.

Swarbrooke, J. (1999). Sustainable Tourism Management. New York: CABI.

Şahin, I. F. (1998). Turistik Aktiviteye Katkıları Yönünden Kızkalesi Kasabası, Türk Coğrafya Dergisi, 33: 349-375.

Tekeli, i. (1971). Bölgesel Turizm Fiziki Planlaması Metodolojisi ile ilgili Düşünceler, Planlama ve Ülkesel Fiziki Planlama Üzerine. Ankara: ODTÜ Mimarlık Fakültesi, Yayın No: 17, s.179-204.

Tekeli, i. (2014). Kültür Politikaları ve Insan Hakları Bağlamında Doğal ve Tarihi Çevreyi Korumak. İstanbul: Tarih Vakfi Yurt Yayınları.

Tekeli, i. (2016). Dünyada ve Türkiye'de Kent Kır Karşıtı̆̆ı Yok Olurken Yerleşmeler İçin Temsil Sorunları ve Strateji Önerileri. Ankara: İdealkent Yayınları.

Tümertekin, E., Özgüç, N. (1998). Beşeri Coğrafya: Insan, Kültür, Mekân. İstanbul: Çantay Kitabevi.

Türkoğlu, H., Korça, P., Köksüz, B. (1989). İkinci Konut Gelişimin Çevresel Etkileri, II. Ulusal Bölge Planlaması Kongresi, iтÜ Mimarlık Fakültesi Baskı Atölyesi:.83-91, İstanbul.

Uryy, J. (2015). Consuming Places. London and New York: Routledge.

Woods, M. (2005). Rural Geography. London: SAGE.

Web 1. "Pelitköy Google Earth Görüntüsü, (Erişim Tarihi: 22.01.2019). https://earth.google.com/web/@39.46399119,26.88738198,7 $8.1225748 a, 5104.49838413 d, 35 y, 0 h, 0 t, 0 r$ 